Sedimentary

Research
Journal of Sedimentary Research, 2017, v. 87, 967-985

Research Article

DOI: http://dx.doi.org/10.21 10/jsr.2017.56
SEPM

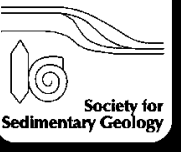

\title{
PETROGRAPHY AND ENVIRONMENTAL INTERPRETATION OF TUFA MOUNDS AND CARBONATE BEDS IN THE JURASSIC NAVAJO SANDSTONE OF SOUTHEASTERN UTAH, U.S.A.
}

\author{
LIAM J. DORNEY,* ${ }^{1}$ JUDITH TOTMAN PARRISH, ${ }^{1}$ MARJORIE A. CHAN, ${ }^{2}$ AND STEPHEN T. HASIOTIS ${ }^{3}$ \\ ${ }^{1}$ Department of Geological Sciences, University of Idaho, 875 Perimeter Drive, Moscow, Idaho 83844-3022, U.S.A. \\ ${ }^{2}$ Department of Geology \& Geophysics, University of Utah, 115 South 1460 East, Room 383, Salt Lake City, Utah 84112-0102, U.S.A. \\ ${ }^{3}$ Department of Geology, University of Kansas, 115 Lindley Hall, 1475 Jayhawk Boulevard, Lawrence, Kansas 66045-7594, U.S.A. \\ e-mail: jparrish@uidaho.edu
}

\begin{abstract}
Carbonate deposits in the Jurassic Navajo Sandstone of Utah reflect deposition in interdune lakes and springs. Interdune-lake deposits consist of flat-lying carbonate units. Springs formed tufa mounds that are interpreted as subaerial, ambient-temperature, artesian-spring deposits. In the first systematic study of the petrography of the carbonate deposits in the Navajo Sandstone, eleven facies were identified in several flat-lying carbonate deposits and two tufa mounds. Fenestral mudstone and peloidal facies dominate the lacustrine deposits, whereas thrombolitic mudstone characterizes the mounds. The biota consists of ostracodes, charophytes, fish, mollusks, a possible freshwater sponge, trace fossils, and fragments of vascular plants. Features resulting from penecontemporaneous weathering provide evidence of episodic exposure of the lacustrine carbonate beds during deposition and formation of the tufa mounds under subaerial conditions. Although carbonate deposits are not rare in eolian systems, few have been studied in detail; comparisons between these and the Navajo Sandstone carbonate deposits reveal some characteristics that may be unique to the latter.
\end{abstract}

\section{INTRODUCTION}

The Lower Jurassic (Pliensbachian-Toarcian) Navajo Sandstone, along with its correlatives, the Nugget Sandstone of southwestern Wyoming and Colorado and the Aztec Sandstone of southern Nevada, formed the largest erg (sand sea) in geologic history (Blakey et al. 1988; Peterson and TurnerPeterson 1989; Kocurek 2003). That the Navajo Sandstone was a subtropical desert is widely accepted (e.g., McKee 1979; Marzolf 1983; Parrish 1993). The desert environment does not, however, preclude processes that involve water, which might have been abundant at times (e.g., Marzolf 1983; Herries 1993; Loope et al. 2001; Eisenberg 2003; Loope and Rowe 2003; Ekdale et al. 2007). Indeed, recent research suggests that water was abundant and had a profound impact on Navajo Sandstone deposition, especially in the eastern portions of the Navajo desert near the erg margin (Chan et al. 2015; Hasiotis et al. 2015, 2016; Parrish et al. 2016, 2017).

The Navajo Sandstone is the upper formation of the Glen Canyon Group (Gregory and Moore 1931; Baker 1936; Averitt et al. 1955; Harshbarger et al. 1957; Lewis et al. 1961; Phoenix 1963; Eppley and Peterson 1979; Peterson and Pipiringos 1979; Condon 1992). The Glen Canyon Group is thickest in the western part of the basin and gradually thins to the east (Blakey et al. 1988; Blakey 2008). Eastward thinning occurs in the direction of the Uncompahgre uplift (Peterson and Pipiringos 1979), a component of the Ancestral Rocky Mountains (Blakey 2008). Early Jurassic paleogeographic reconstructions (e.g., R.C. Blakey, http://jan.ucc.

* Present Address: 2504 Edgehill Avenue, Virginia Beach, Virginia 23454 U.S.A. nau.edu/ rrcb7/200_Jurassic_2globes.jpg, accessed 19 May 2017) show that the Uncompahgre uplift was a positive feature (Blakey 2008).

Carbonate deposits in the Navajo Sandstone constitute 2-3\% of the total volume of the formation (Peterson and Pipiringos 1979). The deposits, which are mainly calcite with minor dolomite, are lenticular and generally $<2 \mathrm{~m}$ thick and $<1 \mathrm{~km}^{2}$ in area (Marzolf 1983; Parrish et al. 2017). The presence of carbonate beds precipitated in an eolian setting is significant because it indicates the presence of water as groundwater, precipitation, or both, despite the desert setting (Pearson and Hanley 1974). Rainfall in the Navajo Sandstone is evidenced by monsoon-rain-driven slumps in the Navajo dunes (Loope et al. 2001). Groundwater influences are indicated by large-scale dewatering structures (Netoff 2002; Chan et al. 2007), conifer logs and stumps (Stokes 1991; Parrish and Falcon-Lang 2007), artesianspring deposits (Parrish and Falcon-Lang 2007; this study), and interdunelake systems (Gilland 1979; Stokes 1991; Eisenberg 2003; Parrish et al. 2017; this study).

Only a few studies have specifically addressed the carbonate deposits in the Navajo Sandstone (Gilland 1979; Stokes 1991; Bromley 1992; Eisenberg 2003; Wilkens and Farmer 2005; Wilkens et al. 2005; Parrish and Falcon-Lang 2007; Dorney and Parrish 2009; Parrish and Dorney 2009; Parrish et al. 2016, 2017). With the exception of one carbonate bed near Moab (Gilland 1979), these have not been studied in detail with respect to their depositional environments and facies. No systematic studies on the petrography of the carbonate deposits in the Navajo Sandstone have been performed to date. Wilkens (2008) presented some thin-section microphotographs, all of which serve as examples of the facies identified here, but did not present a formal facies analysis.

Parrish et al. (2017) identified and classified five types of carbonate mound structures in the Navajo Sandstone. One of the types is tufa mounds 
TABLE 1.-Summary of terms used in this paper and their interpretations.

\begin{tabular}{lll}
\hline \hline \multicolumn{1}{c}{ Term } & Description & Interpretation \\
\hline Carbonate deposit & $\begin{array}{c}\text { All stratigraphically equivalent carbonate rocks at a single } \\
\text { locality } \\
\text { Flat-lying, bedded carbonate (sometimes a single bed) }\end{array}$ & See definition of individual components \\
Carbonate unit & Individual bed in a carbonate unit & Interdune lacustrine deposit \\
Carbonate bed & A mound-shaped body of carbonate much thicker than the & Tufa (spring) mound \\
Carbonate mound & adjacent carbonate unit, if any, with distinctive & Distinct interval of tufa mound accumulation \\
& A stratigraphic division in a carbonate mound & Deposition of sand in a lake or on a mound by a sandstorm \\
Interval & A thin, $<1-$-mm-thick, lamina of quartz grains, very fine & \\
Event horizon & sand- or silt-size &
\end{tabular}

(referred to by some workers as travertine; see Discussion), which they argued are subaerial, ambient-temperature, artesian-spring deposits. More than 200 such mounds have been documented in the Navajo Sandstone, particularly in the region near Moab, Utah (Parrish et al. 2017).

Carbonate deposits are not rare in eolian systems in the geologic record, and they consist of spring mounds or vents, lacustrine deposits, paleosols, and carbonate-sand dunes (e.g., Brooke 2001); speleothems are also common in desert environments (e.g., Brook et al. 1990). The best-known tufa-mound and lacustrine carbonate deposits are from Quaternary and modern deserts in Australia and Africa (Wendorf et al. 1976; Wendorf and Schild 1980; Lancaster and Teller 1988; Teller et al. 1990; Keppel et al. 2011; Rosenberg et al. 2013; Nicoll and Sallam 2016). Nicoll and Sallam's (2016) study on the Kurkur Oasis tufa is exceptional in having a detailed petrographic analysis, but the tufa there is fluvial and the springs apparently did not form mounds.

The purpose of this paper is to apply petrographic techniques to test the hypothesis that the tufa mounds in the Navajo Sandstone are indeed subaerial spring deposits. We performed petrographic analysis of associated and non-associated flat-lying carbonate units - which have been interpreted by all previous workers as interdune-lake deposits - in order to better understand their environments and the roles the springs might have played in their histories.

\section{METHODS}

The terminology used herein for different components of the carbonate deposits is summarized in Table 1.

\section{Sampling}

For this study, we examined two carbonate mounds and their associated carbonate beds, designated sites 1 and 2 northwest of Moab, Utah (Fig. 1); these correspond to the Trough Canyon site of Parrish and Falcon-Lang (2007) and the Horsethief Road site of Parrish et al. (2017), respectively. These two mounds were chosen because they are dissimilar and at least partially exposed in cross section. We also sampled two additional carbonate units from site 1 in order to more fully characterize variation in these environments. Forty-six samples were analyzed petrographically, 20 from site 1 and 26 from site 2. Field relationships were documented for all samples.

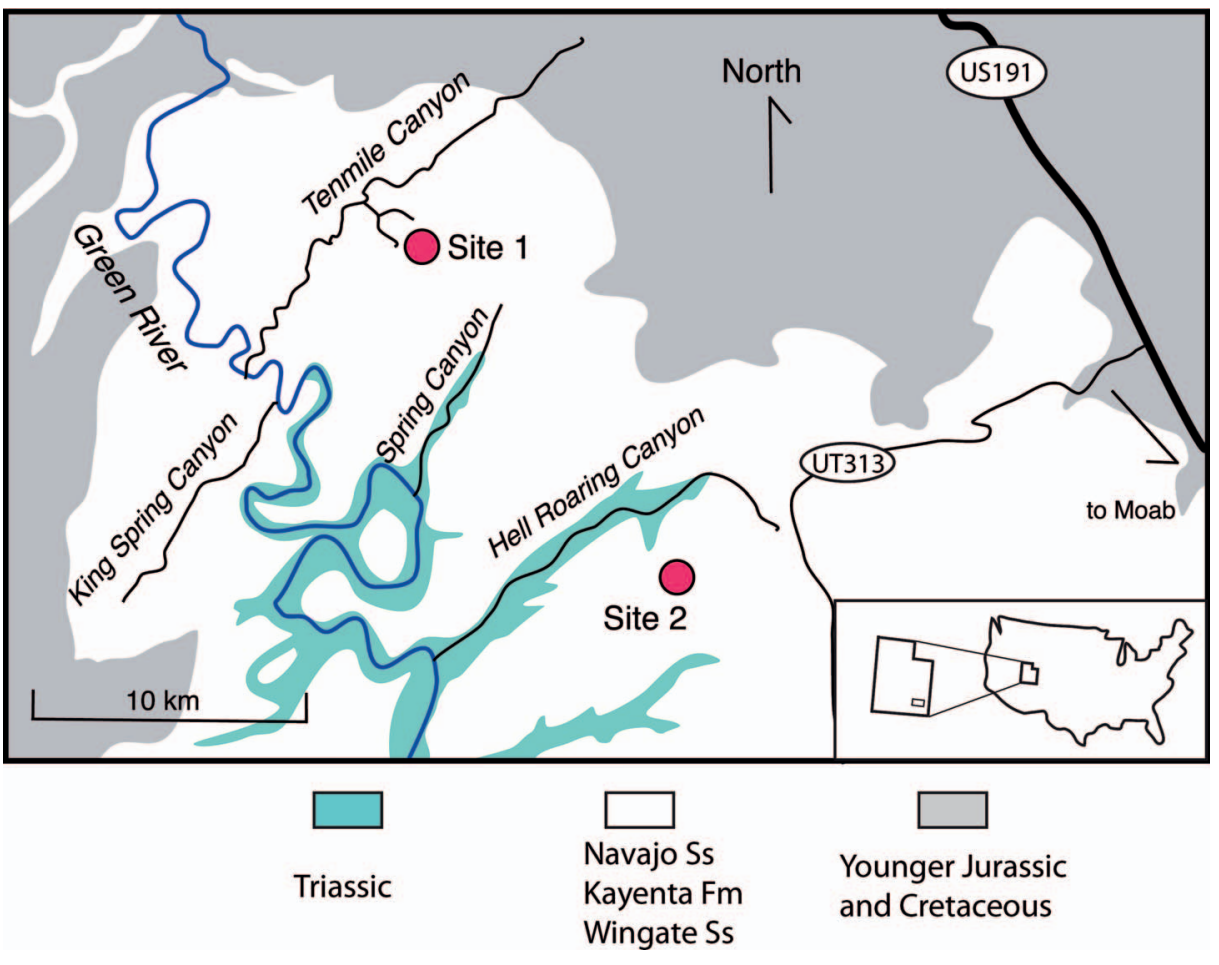

FIG. 1.-Generalized geologic map of sites studied; geologic map from Utah Geological Survey, Quaternary eolian and colluvial deposits omitted. Precise locations are withheld to protect paleontological resources and may be obtained from the Bureau of Land Management office in Moab, Utah. 
Samples from the mounds were taken approximately $10 \mathrm{~cm}$ apart vertically, where practical, and if the lithology changed. Samples of carbonate units were similarly sampled vertically and sampled laterally where there were notable lithologic changes.

\section{Petrography}

A representative portion of each of the 46 samples was selected for thinsection examination; standard or large-size thin sections were used, depending on features in the hand sample. The thin sections were examined under plane-polarized and cross-polarized light, using an Olympus BX51 microscope and an attached Olympus DP70 camera for photomicrographs. Thin sections were stained with Alizarin Red S (ARS) and potassium ferricyanide to identify ferroan-nonferroan calcite and dolomite (Dickson 1965; Hutchison 1974). Petrographic analysis included sedimentary structures; texture; porosity; skeletal, carbonate, and clastic grains; and cement. Facies descriptions follow the Dunham classification and were aided by published photographs in numerous sources (Scholl 1960; Pratt and James 1982; Arp et al. 1998; Riding 2000; Scholle and Ullmer-Shcolle 2003; Flügel 2004; Johnson et al. 2009; GierlowskiKordesch 2010; Benavente et al. 2015; Chidsey et al. 2015). We did not perform point counts; rather, we estimated grain concentrations based on visual estimates of areal coverage in the thin sections. We acknowledge the potential inaccuracy of this method (Dennison and Shea 1966), but our analysis of the facies does not depend on single-digit precision. In addition, although we noted the types of porosity, we did not quantify them because the facies are so variable that an analysis of 46 samples was unlikely to yield statistically significant results. Facies were defined based on the characteristics of outcrop expressions, hand samples, and thin sections.

\section{RESULTS AND INTERPRETATIONS}

In the following sections, we present the results of the petrographic analysis and identification of facies, followed by field observations and the vertical and lateral distribution of the facies at each site. Sample locations are in Supplemental Figures 1 and 2, and a complete petrographic description of each sample is presented in Supplemental Tables 1 and 2.

\section{Carbonate Facies}

We identified 11 carbonate facies, most of which have laminated, thrombolitic, or peloidal textures. The thin-section characteristics of the facies are described in Table 2, and a summary of the facies for each site is in Table 3. We interpret and discuss the facies in the following section and present information about and interpretation of penecontemporaneous weathering, the biota, nonskeletal grains, mineralogy, and porosity in the subsequent sections.

Facies Interpretations.-The fenestral mudstone facies (Fig. 2A) is interpreted to be microbial in origin, following the classification of Riding (2011). The three laminated fenestral mudstone facies (Fig. 2B-D) are gradational from slightly hummocky or wavy to irregularly to highly irregularly laminated. These are the dominant facies and, with one exception, in the carbonate mound at site 1 , occur in the carbonate units. We interpret these facies as stratiform stromatolites (Pratt and James 1982; Riding 1999; also referred to as "cryptalgalaminates" by Aitken 1967 and "microbial laminites" by Parcell 2002) because they are finely laminated in thin section and hand sample, composed entirely of calcite, and nonisopachous, consistent with an organic, microbial origin (Aitken 1967; Pope and Grotzinger 2000; Riding 2000; Gierlowski-Kordesch 2010). Stromatolitic structures such as columnar, cylindrical, or domal micro- or mesostructures (e.g., Gierlowski-Kordesch 2010; Guo and Chafetz 2012; Della Porta 2015; Dabkowski et al. 2015b), are absent and, in fact, are rare in the Navajo Sandstone carbonate deposits as a whole (Parrish et al. 2017). The gradation from laminated to highly irregularly laminated may represent an increase in exposure to the atmosphere and consequent disruption by wind, insects (Hasiotis et al. 2015, 2016), or other organisms, and/or desiccation (Hanley and Steidtmann 1973). Evidence of penecontemporaneous weathering and desiccation (see below) is more common in the highly irregularly laminated fenestral mudstone (hereafter referred to as HIL fenestral mudstone; Fig. 2D) facies, supporting the interpretation that this facies was indicative of greater exposure (Riding 2000). However, not all examples of this facies contain evidence of exposure. Bioturbation is unlikely to be the sole mechanism for the genesis of the highly irregular laminations because, when burrows are observed, they completely disrupt the lamination.

Thrombolitic mudstone (Fig. 3) is also common in these rocks, especially in the carbonate mounds. Thrombolites are also microbial (e.g., Aitken 1967; Schmid 1996; Parcell 2002; Shapiro 2000; Riding 2011; Bosence et al. 2015). The clotted nature of the thrombolitic mudstone is usually visible only thin section, and we find no diffuse vertical branching micro- or mesostructures such as those illustrated by Pratt and James (1982), Kennard and James (1986), Shapiro (2000), and Raviolo et al. (2010; see also Riding 2000). One sample from a thrombolitic mudstone contains filamentous structures we interpret as microbial microborings (Fig. 3B, C; Buijs et al. 2004).

Peloidal facies - packstone, wackestone, and grainstone (Fig. 4) - are also regarded as typical of microbialites (Bosence et al. 2015). Peloids may be the result of desiccation (Demicco et al. 1987) or bioturbation of microbial structures (Gierlowski-Kordesch 2010) and are also found in stromatolitic (Riding 2011) and thrombolitic (Schmid 1996; Chidsey et al. 2015) structures. However, peloidal facies in this study are generally massive and rich in ostracodes and charophytes, although faint laminations may be present.

The vuggy intraclastic mudstone facies (Fig. 5A) is found in a single sample from the mound at site 2. Vuggy porosity is typical of freshwater carbonate deposits (i.e., tufa; Pedley 2009; Della Porta 2015), where it is primary, and we interpret this vuggy texture to be one of the indications that the carbonate mound was a spring deposit. Although Driese (1985) described vugs in carbonate beds in the eolian Weber Sandstone as being pseudomorphs after anhydrite nodules, those occur in flat-lying carbonate beds and in no way resemble the vugs found in this facies of the Navajo Sandstone.

The bioclastic grainstone facies (Fig. 5B, C) occurs in one sample from site 2 . We interpret this facies to represent an event that disrupted the surface of the mound (see interpretation of site 2).

Penecontemporaneous Weathering.-Circumgranular cracking, microkarst (sensu Freytet and Verrecchia 2002), and in situ brecciation are present in some samples (Fig. 6). Circumgranular cracking is mostly in the HIL fenestral mudstone facies, but it does occur in other samples (Supplemental Table 1). Microkarst is recognized by truncation of features in the lower surface (Fig. 6A) and by terra rossa in the corresponding hand samples; it occurs in several facies (Supplemental Table 1). In situ brecciation also occurs in several facies, including the HIL fenestral mudstone (Supplemental Table 1). We attribute these features to penecontemporaneous weathering, with the brecciation representing a slightly more advanced stage of weathering, resulting in early-stage dissolution collapse and cementation. In thin section, the thickness of the weathered rock is generally $<5 \mathrm{~mm}$; thicker terra rossa horizons are as much as a centimeter thick. No modern terra rossa was observed.

Biota.-The biota consists mostly of microbial structures; in one case we were able to image probable microbial microborings (Fig. 3B, C). Ostracodes are abundant in some samples and facies, and charophyte oogonia (Fig. 4D) are common (Supplemental Table 1). Rare occurrences 
TABLE 2.-Descriptions of facies in thin section from carbonate deposits of the Navajo Sandstone. Three-digit numbers beginning with " 0 " and the number 1705001 refer to the sample numbers (see Supplemental Tables 1 and 2).

FACIES (samples)

Fenestral mudstone $(008,011,036)$

Laminated fenestral mudstone $(003,010,035,040,049)$

Irregularly laminated fenestral mudstone $(037,039,041,042)$

Highly irregularly laminated fenestral mudstone $(006,016,021)$

Thrombolitic mudstone* $(027,028,030,031,032,034,046,047,1705001)$

Peloidal packstone $(002,004,012,013,014,020,023,045,048)$

Peloidal grainstone (001)

Peloidal wackestone $(005,007,009,015,017,022,024,044)$

Vuggy intraclastic mudstone (043)

Bioclastic grainstone (029)

Chert and siliciclastics $(018,19 \mathrm{~A}, 19 \mathrm{~B})$

\section{FIGURE \#}

$2 \mathrm{~A}$

2B

$2 \mathrm{C}$

2D

3

$4 \mathrm{~A}$

4B

4C, D

$5 \mathrm{~A}$

$5 \mathrm{D}$
DESCRIPTION

Fine-grained to micritic, lamination lacking; fenestral porosity; varying amounts of quartz, evenly distributed; quartz grain size varies; predominantly calcite, except 008 (40\% dolomite)

Fine-grained to micritic, hummocky lamination; fenestral porosity; single-seam and/or swarm stylolites, stylobedding; varying amounts of quartz, mostly along lamina boundaries, some dispersed; predominantly calcite with some ferroan calcite in pore spaces in 049; circumgranular cracking in 040

Irregular wavy lamination; laminae deformed; abundant intraclasts; clotted fabrics; stylomottling; variable quartz content; silt and sand laminae $>5 \mathrm{~mm}$ thickness in two samples; one sample (042) burrowed; calcite

Highly irregular lamination; stylolites; vugs common; fenestral porosity usually filled with silt- and sand-size quartz grains; circumgranular cracking; calcite or, rarely, ferroan calcite

Fine-grained to micritic; diffuse clotted textures; vuggy, channel, fenestral pore spaces; filamentous structures (sample 030, Fig. 3A); predominantly calcite, with some ferroan calcite and dolomite, dolomite $85 \%$ in one sample

Peloidal textures; massive where found in carbonate beds under the carbonate mounds, massive to irregularly laminated in other lacustrine carbonate beds; predominantly fenestral porosity, with some vuggy porosity and uncommon channel porosity; ostracodes, charophytes; poorly sorted quartz sand grains; calcite, with minor ferroan calcite

Peloidal texture pervasive; irregular and wavy lamination; fenestral porosity; stylolites; intraclasts on pressure-solution planes; microkarst; calcite with minor ferroan calcite

Peloidal textures in fine-grained to micritic matrix; massive to irregularly laminated; fenestral, vuggy, or channel pore spaces, with vuggy porosity dominating; charophytes and ostracodes in samples from carbonate units; quartz sand grains common, but less abundant in the carbonate mound sample (016); calcite, with ferroan calcite in some samples

Massive, leiolitic to clotted; vugs up to $2 \mathrm{~cm}$ across throughout; angular intraclasts throughout; vuggy, fenestral, channel porosity propagating from vugs; circumgranular cracking; stylolites; small amounts of quartz grains along stylolites; calcite

Massive; bioclasts, including ostracodes, fragments of microbial crusts, pelecypod; vuggy porosity; geopetal structures; calcite with minor dolomite

Silicified mixed siliclastic grains and carbonate mudstone or chert; no porosity; remnants of peloids and a possible freshwater sponge in the silicified mudstone; silicified mudstone is $\sim 55 \%$ carbonate, $30 \%$ calcite with minor ferroan calcite and dolomite

\footnotetext{
* Definition after Shapiro (2000)
}

include a fish scale, which occurs in a carbonate bed at site 2 , and a pelecypod shell with simple ornamentation (Fig. 5C). In addition, an enigmatic structure that is possibly a sponge was observed in one sample (Fig. 5D); freshwater sponges are known from the Upper Jurassic Morrison Formation (Dunagan 1999).

Because of the poor preservation, we did not attempt to identify the organisms taxonomically, but at another locality Wilkens (2008) identified ostracodes as belonging to the common freshwater genus Darwinula, and pelecypods from the freshwater genus Unio. The fish scale is typical of actinopterygians, which were recently reported for the first time from the Navajo Sandstone (Frederickson and Davis 2017).

Ostracodes mainly inhabit lakes and streams, but are small and motile, meaning that they can theoretically live in any aquatic environment, including surface waters of subaerial spring mounds. Although we found no reports of a spring habitat for ostracodes in the literature, that is likely because of the paucity of modern subaerial, ambient-temperature spring mounds (Jones and Renaut 2010; Keppel et al. 2011; see Discussion).

Nonskeletal Grains.-Nonskeletal carbonate grains are present in numerous facies (Supplemental Table 2). These include intraclasts, ooids, oncoids, pisoids, and fecal pellets; none of these, except for the intraclasts, is common. The intraclasts are rarely $>1 \mathrm{~mm}$ long, more commonly $<0.5$ $\mathrm{mm}$, and appear to be autochthonous. We interpret these to be the result of in situ disturbance by aquatic organisms. Intraclasts are typical of palustrine environments (Alonso-Zarza 2003) although, in the samples studied here, also occur in the carbonate mounds. 
TABLE 3.-Summary of the distribution of facies in samples from sites 1 and 2 .

\begin{tabular}{|c|c|c|c|c|}
\hline \multirow[b]{2}{*}{ Facies } & \multicolumn{2}{|c|}{ Site 1} & \multicolumn{2}{|c|}{ Site 2} \\
\hline & $\begin{array}{l}\text { Tufa } \\
\text { mound }\end{array}$ & Lakes & $\begin{array}{l}\text { Tufa } \\
\text { mound }\end{array}$ & Lake \\
\hline Fenestral mudstone & & $\mathrm{x}$ & & $\mathrm{x}$ \\
\hline Laminated fenestral mudstone & & $\mathrm{x}$ & & $\mathrm{x}$ \\
\hline Irregularly laminated fenestral mudstone & & & & $\mathrm{x}$ \\
\hline Highly irregularly laminated fenestral mudstone & $\mathrm{x}$ & $\mathrm{x}$ & & $\mathrm{x}$ \\
\hline Peloidal packstone & & $\mathrm{x}$ & & $\mathrm{x}$ \\
\hline Peloidal wackestone & $\mathrm{x}$ & $\mathrm{x}$ & & $\mathrm{x}$ \\
\hline Peloidal grainstone & & $\mathrm{x}$ & & \\
\hline Thrombolitic mudstone & $\mathrm{x}$ & & $\mathrm{x}$ & $\mathrm{x}$ \\
\hline Vuggy intraclastic grainstone & & & & $\mathrm{x}$ \\
\hline Bioclastic grainstone & & & $\mathrm{x}$ & \\
\hline Chert and siliciclastics & $\mathrm{x}$ & & & \\
\hline
\end{tabular}
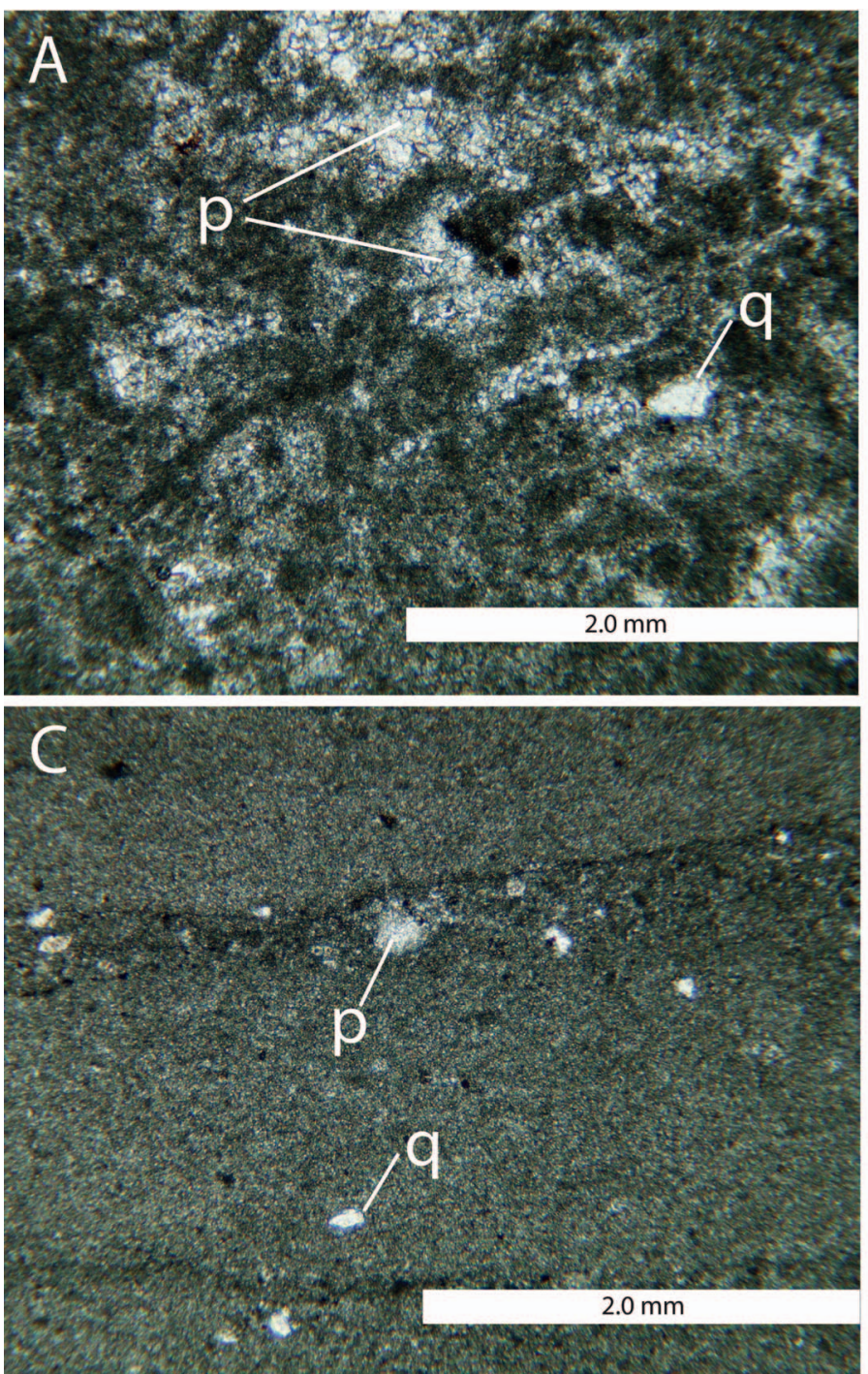

Mineralogy.-Given that the Navajo Sandstone is predominantly eolian quartz sand, as expected, quartz grains are common in the carbonate rocks. Quartz content is variable in all carbonate facies represented by more than one sample, ranging from $<1 \%$ to as high as $50 \%$, and ranging in size from silt to very fine-grained sand. Quartz grains may be dispersed (e.g., Fig. 3A), concentrated along stylolites (e.g., Fig. 2D), or concentrated in layers referred to here as event horizons (e.g., Fig. 4C). The event horizons are very thin-3 to 10 grains thick. They show no evidence of hydrodynamic transport, can be continuous over several meters in the carbonate units, and are almost entirely very fine-grained sand. We interpret the event horizons to represent unusually strong wind events during which wind-blown sand was dropped into the lakes or adhered to the wet mound surfaces.

Calcite is the dominant mineral, with minor amounts of dolomite and ferroan calcite. All samples show some degree of recrystallization. In general, the carbonate grain sizes range from $<1 \mu \mathrm{m}$ to $5 \mu \mathrm{m}$. A few samples are more coarsely recrystallized and/or partially replaced with chert. In only three samples is dolomite a significant ( $>5 \%)$ component; it is either micritic or in rhombs. Dolomite is not systematically associated
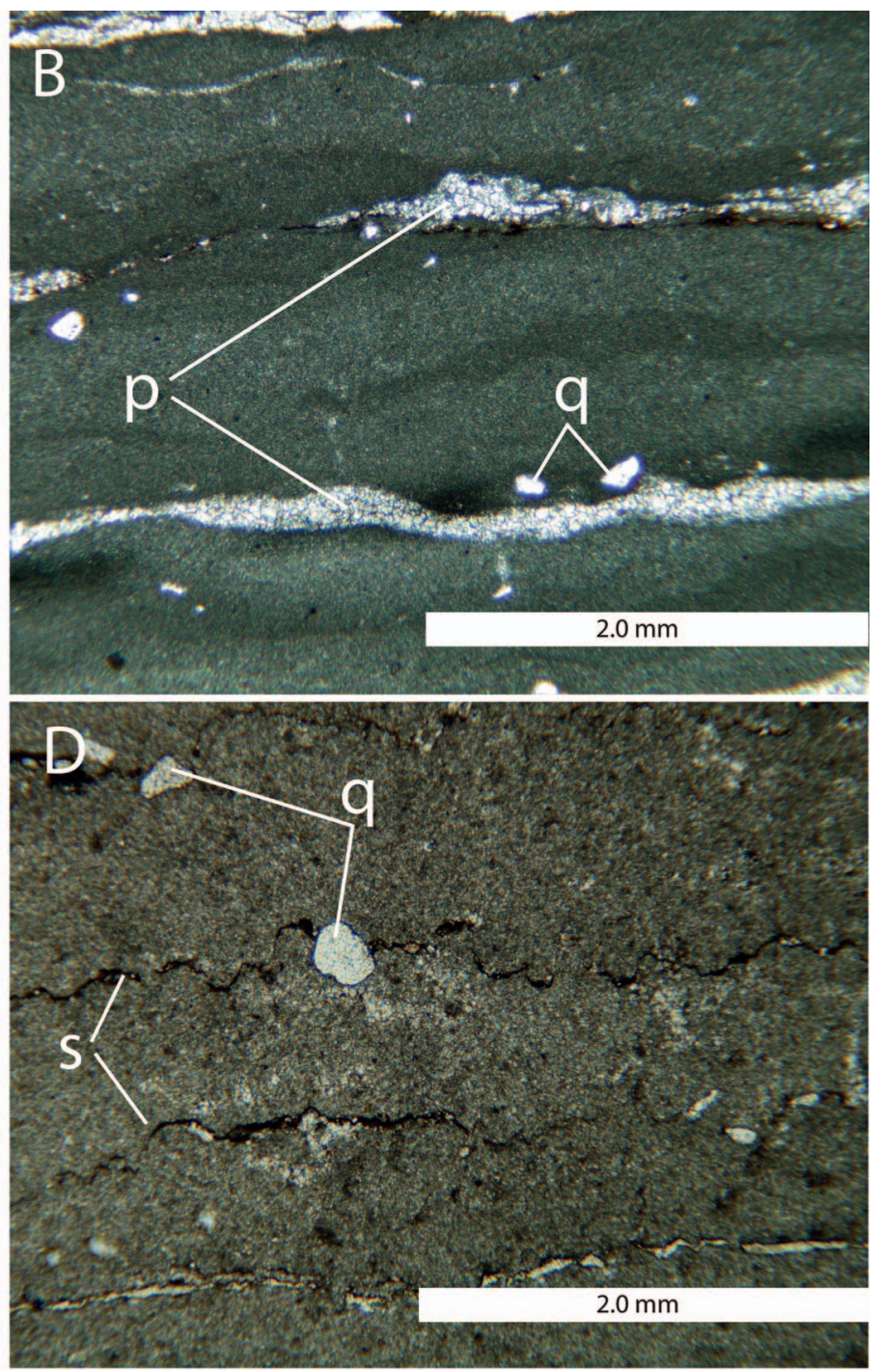

FIG. 2. - Oriented thin sections representative of carbonate facies. A) Fenestral mudstone facies; from sample 008. B) Laminated fenestral mudstone facies; from sample 010. C) Irregularly laminated fenestral mudstone facies, intraclasts not shown; from sample 042. D) Highly irregularly laminated fenestral mudstone facies; from sample 016. p, calcite-filled pore; q, quartz grain; s, stylolite. 

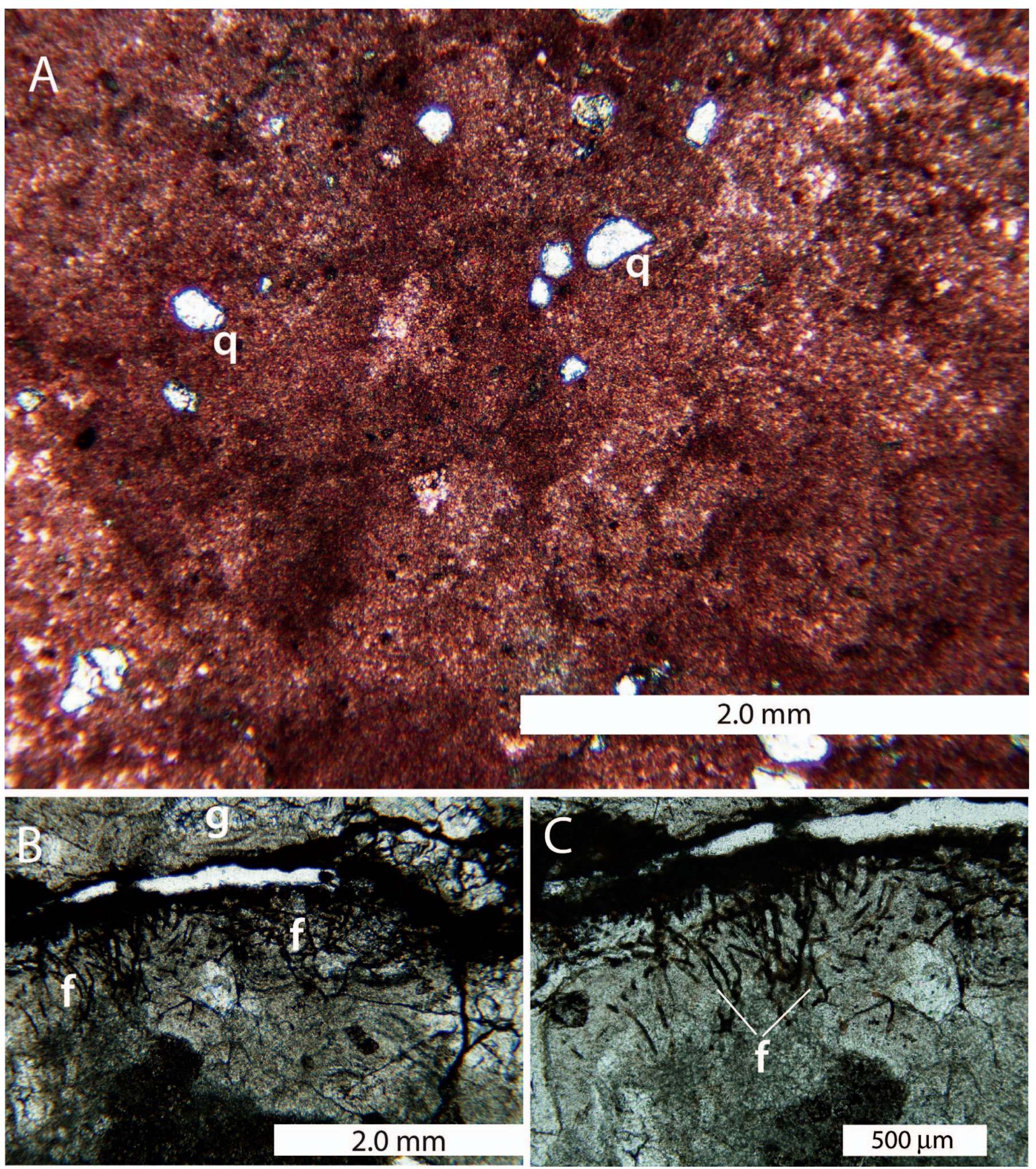

FIg. 3. - Oriented thin sections of the thrombolitic mudstone facies. A) Representative thin section, showing clotted texture and scattered quartz grains (q); from sample 046. B) Thin section showing microbial microborings along a channel pore space; $f$, location of most microborings; $g$ is an area where the linear features are calcite grain boundaries; from sample 030. C) Close-up of microborings in Part B; f, microboring with lines pointing to two of them. Note branching microboring at right-hand line. 

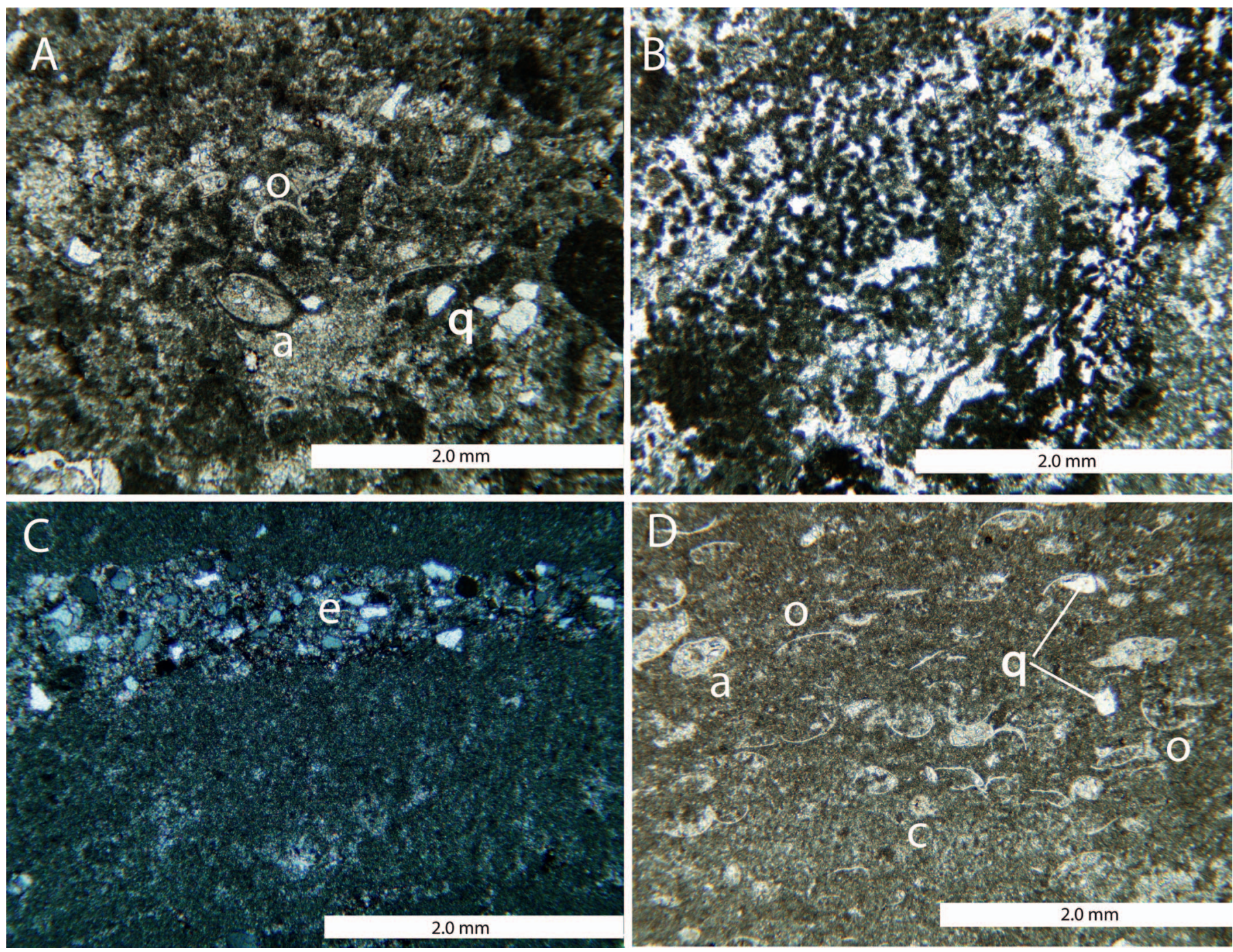

FIG. 4. - Oriented thin sections of the peloidal facies. A) Peloidal packstone facies; a, articulated ostracode; o, disarticulated ostracodes; q, cluster of quartz grains (not all quartz marked); from sample 012. B) Peloidal grainstone facies; white areas, pores filled with calcite; microkarst and intraclasts not shown; from sample 001. C) Peloidal wackestone facies; e, quartz grain event horizon; crossnicols; from sample 017. D) Peloidal wackestone facies; a, articulated ostracodes (not all marked); o, disarticulated ostracodes (not all marked); c, charophyte; q, quartz grains; from sample 005.

with pore spaces (Pedone and Dickson 2000). Dolomite occurs in palustrine environments (Freytet and Verrecchia 2002; Cabaleri and Benavente 2013; Cabaleri et al. 2013; Casado et al. 2014), and may be primary (Casado et al. 2014). Dolomite can also be a microbially mediated primary precipitate in spring deposits (García Del Cura et al. 2014). A systematic analysis of the dolomite remains a subject for future studies. Ferroan calcite is rare.

Chert is mostly in the form of flattened nodules at these sites and elsewhere in carbonate units of the Navajo Sandstone (Parrish et al. 2017). There are three possible sources of the silica: hydrothermal, biogenic, or chemical precipitate from dissolved quartz grains or volcanic ash. We argue here that the mounds are not hydrothermal (see Discussion), and thus rule out silica-rich hydrothermal water as the source. A biogenic source is possible, given the possible presence of sponges (Fig. 5D). Microbial mediation of dissolution and precipitation of silica from the quartz grains is also possible (e.g., Brehm et al. 2005), although we have no way to directly test this. Finally, we note that silicified wood is abundant in the Navajo Sandstone (Parrish et al. 2017), as it is throughout the Mesozoic of the Colorado Plateau. Volcanic ash is considered the main source of silica for this fossilization (e.g., Sigleo 1979), and the volcanic arc to the west was active at this time (Riggs and Blakey 1993).

Porosity.-The samples contain three main porosity types (Choquette and Pray 1970) - fenestral, channel, and vuggy. The most important type is vuggy porosity, and it is not limited to the vuggy intraclastic mudstone facies (Supplemental Table 1). Vuggy porosity in tufa deposits is primary, and initial porosity can be as high as 50-60\% (e.g., Pentecost 2005; Pedley 2009; Della Porta 2015). In the Navajo Sandstone, much original porosity is filled with cement, but some has remained. Evidence that this is secondary porosity, such as partial dissolution of carbonate grains, is lacking.

\section{Field Relationships, Facies, and Interpretation-Site 1}

Description.-Site 1 is characterized by three carbonate units (lower, middle, and upper) interbedded with sandstone (Fig. 7; Parrish and FalconLang 2007), and the carbonate mound studied is associated with the middle limestone unit (Figs. 8, 9). Facies in the carbonate mound and carbonate units are illustrated in Figure 9. 

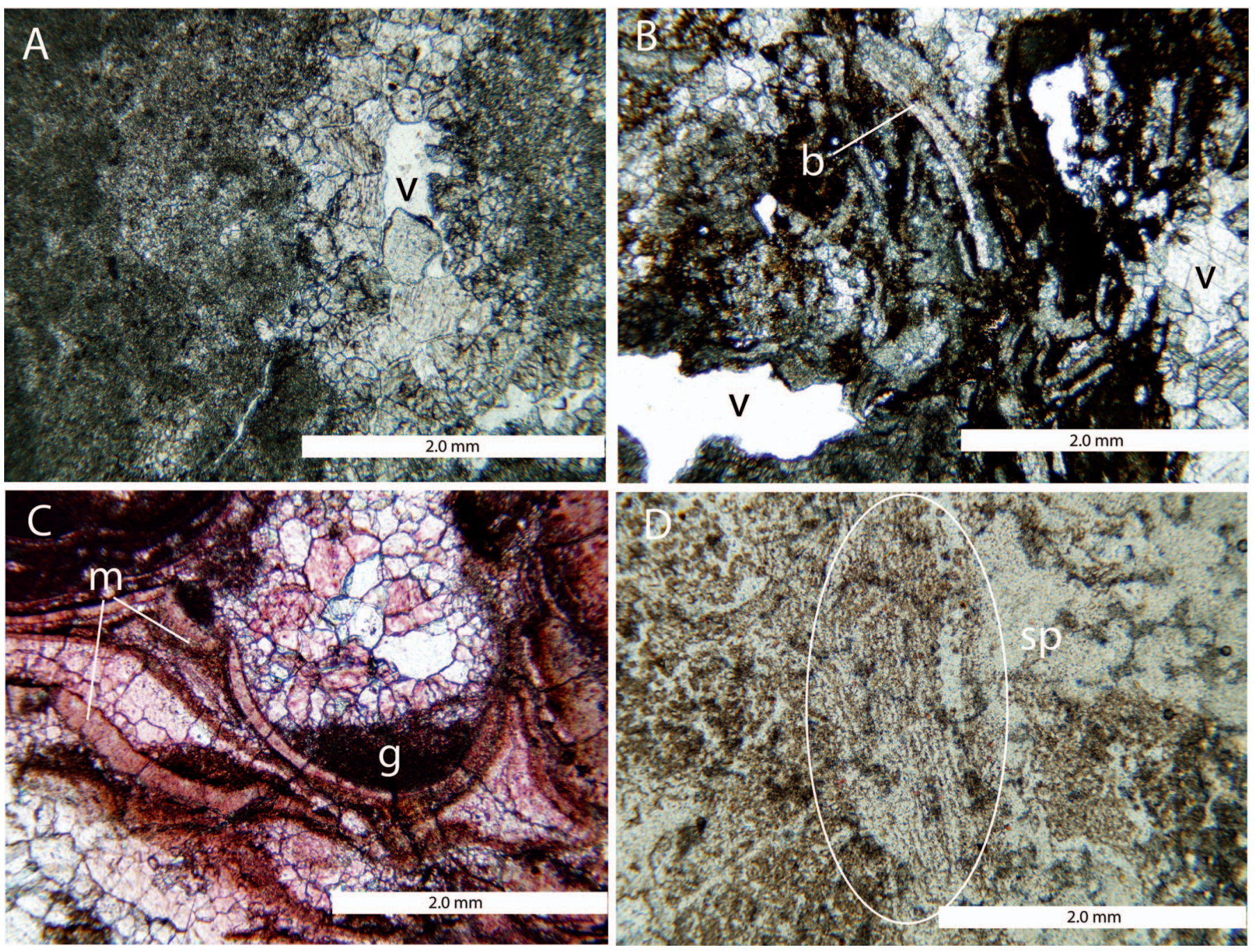

FIg. 5.-Oriented thin sections representative of carbonate facies. A) Vuggy intraclastic mudstone facies; v, vug partially filled with sparry calcite; intraclasts not shown; from sample 043. B) Representative thin section of the bioclastic grainstone facies; b, bioclast, probably a rip-up clast of microbial crust; $v$, open (lower left) and calcitecement-filled (right) vugs; from sample 029. C) Bioclastic grainstone facies; g, geopetal fill, with sparry calcite cementing the rest of the cavity formed by curvature of the shell; m, pelecypod shell; from sample 029. D) Chert and siliciclastics facies, entirely chert in this field of view; sp, possible sponge, inside oval; from sample 019.

The lower carbonate unit is not associated with carbonate mounds. Ostracodes occur throughout, and the upper surface of this carbonate unit has gypsum-crystal molds and, in places, centimeter-thick terra rossa. The middle beds of the lower carbonate unit extend eastward and pinch out. Near the pinch-out, all facies contain ostracodes, and the upper peloidal packstone has charophytes; these facies also contain some of the highest quartz-grain contents $(25-40 \%)$ of any samples in this study. The lower carbonate unit is underlain by massive sandstone, which, in turn, is underlain by a thick sandstone interval with large-scale crossbeds.

The middle carbonate unit is associated with the carbonate mound studied here. This unit also contains ostracodes throughout. The peloidal grainstone contains charophytes, fragments of vascular plants, microkarst, several event horizons, and irregular lamination. The relationship of this unit with the carbonate mound is ambiguous. The unit does not reach the mound on the west side. On the east side, the lateral relationship is covered. The lowest bed at the base of the mound (sample 014, Supplemental Fig. 1) may be a continuation of the middle carbonate extending under the mound; it contains ostracodes and charophytes. The middle carbonate is underlain and overlain by massive and cross-bedded sandstone (Fig. 7).
The upper carbonate unit is variable, discontinuous, and less extensive than the lower two units (Parrish and Falcon-Lang 2007); it is associated with small carbonate mounds. The unit is stratigraphically above the carbonate mound in the middle unit but found only to the west. The fenestral mudstone at the base (Fig. 9) is very dolomitic (40\%; Supplemental Table 1). The middle sample has charophytes and ostracodes; the upper one has ostracodes and a discontinuous event horizon.

The carbonate mound at site 1 is $\sim 4 \mathrm{~m}$ high (Fig. 10). Assuming that the lowest bed is an extension of the middle carbonate unit and not part of the mound, the mound itself is divided vertically into four intervals (Figs. $9,10)$ that are inclined toward the north (toward viewer in Fig. 10). This inclination is $30^{\circ} \mathrm{N}$ and is primary depositional dip down the side of the mound; regional structural dip is $\sim 5^{\circ} \mathrm{N}$. The lower (inner, toward the core of the mound) part of the lower interval is peloidal wackestone with microkarst. The upper (outer) part is HIL fenestral mudstone with a few ostracodes, circumgranular cracking, and a sandstone lens $2 \mathrm{~mm}$ thick, thicker than most event horizons.

The middle two intervals are the only representatives of the mixed siliciclastics and chert facies in this study (Fig. 9). Chert has obscured most 

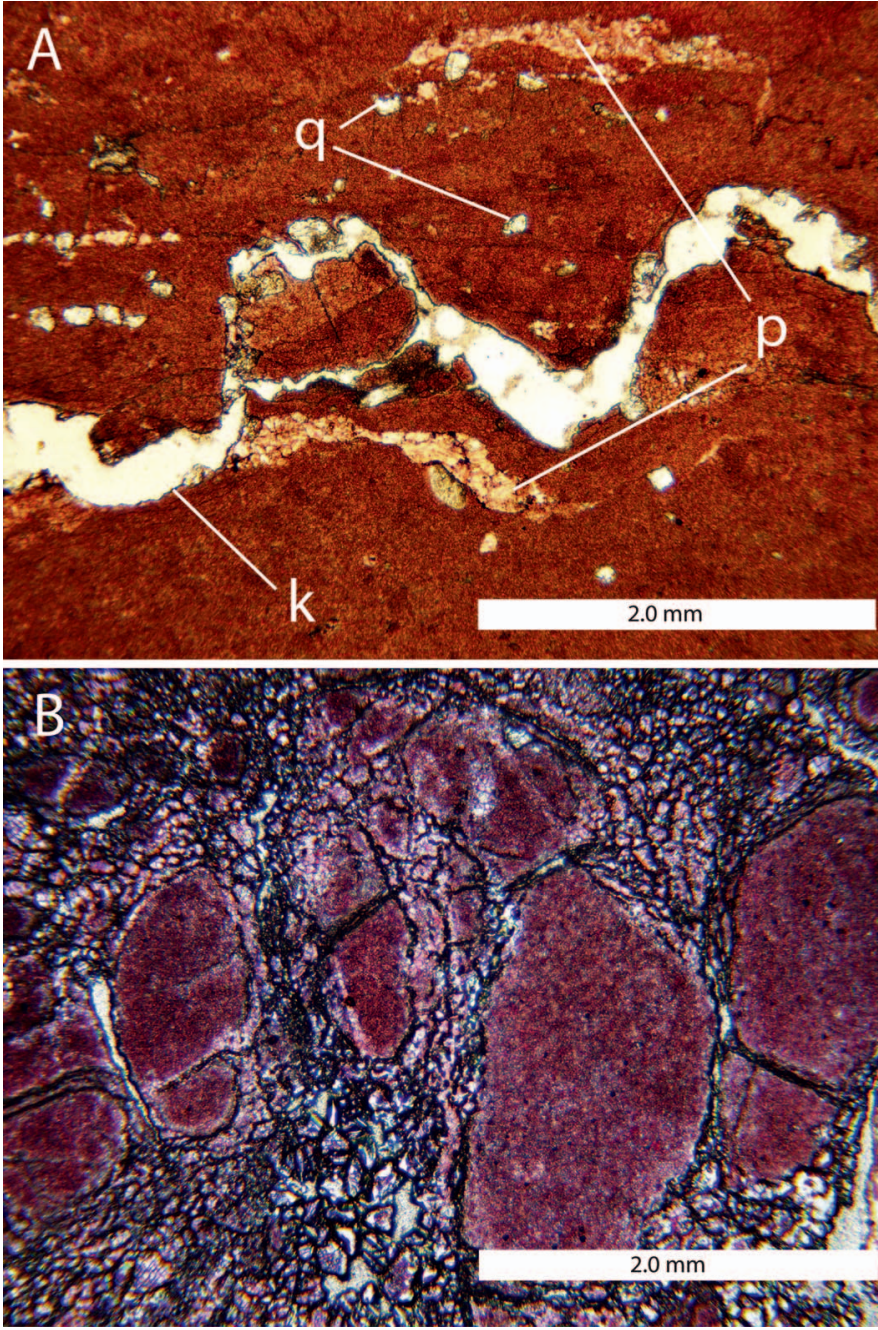

FIG. 6.- Oriented thin sections of microkarst and weathering brecciation. A) Microkarst; k, weathering surface; $\mathrm{p}$, fenestral pore spaces; q, quartz grains (not all marked); from sample 049. The karst surface is confirmed as a weathering feature by truncation of the lower fenestral pore and by terra rossa in the hand sample. B) In situ weathering brecciation; from sample 015 . The large, rounded clasts are unaltered carbonate mudstone, rounded by dissolution and surrounded by recrystallized calcite.

of the original fabric. In the lower middle interval, the remaining fabric is consistent with thrombolitic mudstone. The upper middle mound interval is vuggy, brecciated, and cherty, and consists mostly (75\%) of quartz sand grains. The original carbonate fabric appears to have been peloidal packstone or wackestone. The upper interval is a strongly dolomitized $(85 \%)$ thrombolitic mudstone with few quartz grains.

Sandstone adjacent to the carbonate mound on the east is massive, grading upward into cross-bedded sandstone overlain in turn by another bed of cross-bedded sandstone. The upper cross-bedded sandstone bed dips toward the carbonate mound. On the west side of the carbonate mound, the lower sandstone bed is massive and overlain by cross-bedded sandstone that pinches out farther west, forming a wedge (see Interpretation).

Interpretation.-We interpret the carbonate units to be interdune lakes based on their overall stratigraphic character. They are flat lying, extend for tens to hundreds of meters laterally, and, with the exception of the truncated upper carbonate unit, pinch out into higher-order stratigraphic

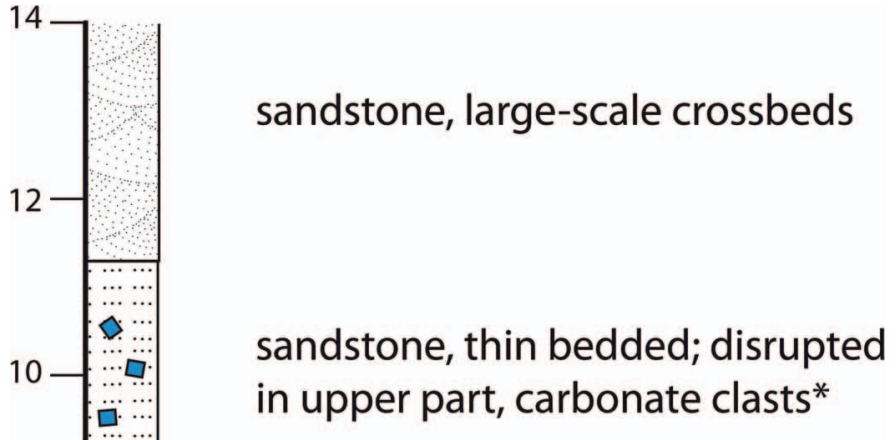

sandstone, lenticular crossbedded

\section{middle carbonate unit}

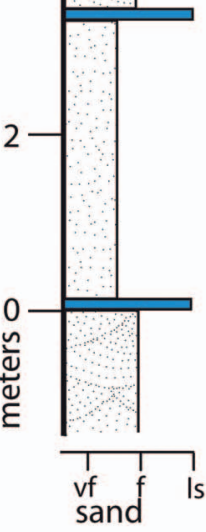

sandstone, massive

lower carbonate unit

sandstone, large-scale crossbeds

\section{*equivalent to the upper carbonate unit}

FIG. 7.- Section I from Parrish and Falcon-Lang (2007), showing the stratigraphic context for the carbonate deposits at Trough Canyon. Thick sandstone units above and below the section were not measured. The carbonate mound is equivalent to but south of the middle carbonate unit in this section. Neither the bottom nor the top of the Navajo Sandstone is exposed at this site.

bounding surfaces typical of eolian sequences (Brookfield 1977; Kocurek 1988). Carbonate deposition in the lakes was terminated either by desiccation or burial by migrating dunes.

The lower carbonate unit is dominated by peloidal facies (Fig. 9), but HIL fenestral mudstone and fenestral mudstone are also present. The presence of ostracodes throughout supports the interpretation of this unit as an interdune lake. Circumgranular cracking and in situ brecciation in the HIL fenestral mudstone indicates that this facies likely represents a lake lowstand. Terra rossa in the laterally equivalent beds, close to where the unit pinches out (Fig. 9), also indicate that the lake dried episodically. The lower carbonate unit near the pinch-out must have been closest to the lake margin, a conclusion supported by the abundance of terra rossa and the high content of quartz sand in samples from this part of the unit. Gypsum- 


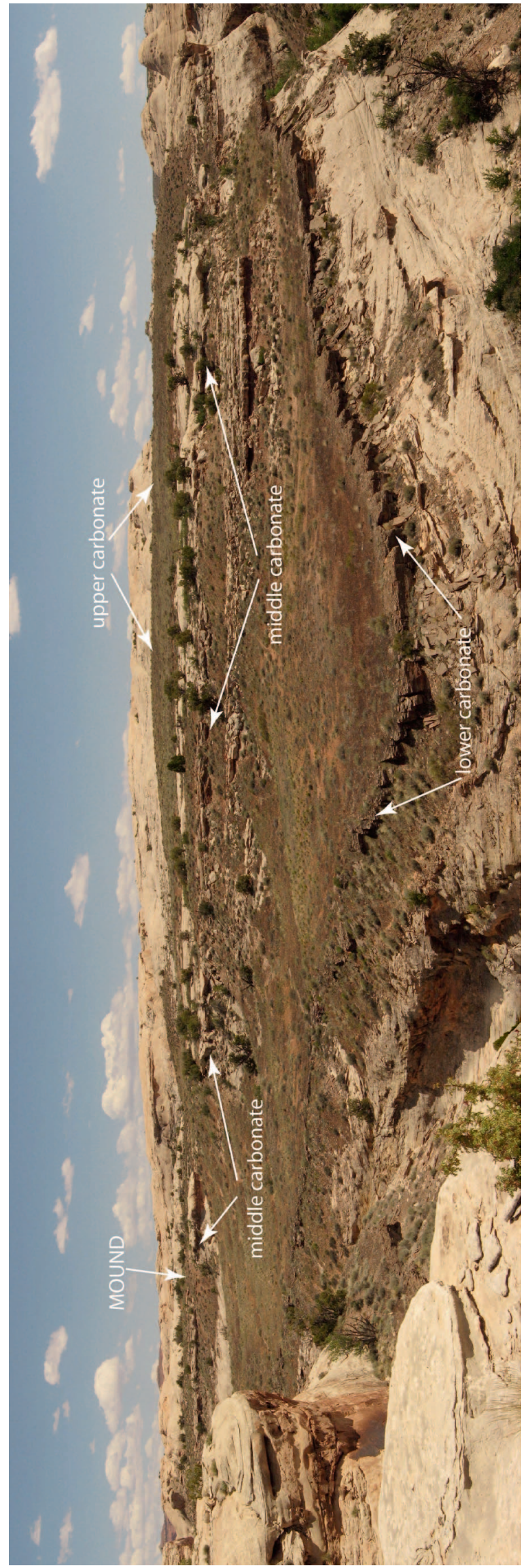

crystal molds and terra rossa at the top of the unit demarcate the final desiccation of the lake. The gypsum-crystal molds are scattered on the bed surface rather than concentrated; enough sulfate was probably delivered by wind or groundwater circulation from salts in the Paradox Formation, which underlies parts of this area (Drake et al. 2004; Blakey 2008), that no unusual chemistry of the lake water is required to explain the presence of gypsum.

The upper carbonate unit lacks evidence for episodic desiccation. An ostracode coquina in the peloidal wackestone (Fig. 9) suggests an episode of agitation and sorting of the sediment by wind or other organisms. We speculate that the high amount of dolomite in the fenestral mudstone at the base of the unit is related to some unidentified abnormal condition, not inherent to the facies itself, as the facies here also lacks ostracodes. The other example of fenestral mudstone, from the middle carbonate unit, lacks dolomite and has ostracodes.

In the middle carbonate unit, normal lake sedimentation, with ostracodes and charophytes, took place early in its deposition. The lake dried and microkarst formed after deposition of the peloidal grainstone in the lake proper, west of the mound (Fig. 9), but other evidence for desiccation is lacking.

We interpret the carbonate mound at site 1 to be a tufa mound formed by an artesian spring, as we do all such mounds in the Navajo Sandstone (Parrish et al. 2017). The lowest interval in the tufa mound is the best exposed. The inclination of the interval toward the north is evidence that the mound formed subaerially; such drapes are typical of subaerially deposited tufa (e.g., Jones and Renaut 2010; Arenas-Abad et al. 2010). The peloidal facies in the inner part of this interval suggests the possibility that the lake was there first and that the earliest stage of mound growth might have been sublacustrine. However, the absence of ostracodes contradicts this. The outer part of this interval, which is HIL fenestral mudstone, does contain ostracodes, but the highly irregular lamination and circumgranular cracking in this facies are consistent with subaerial exposure. This evidence, and the fact that the middle carbonate unit does not reach the mound on the west side, is consistent with the hypothesis that the spring was subaerial and flowed asymmetrically during its initial stages, possibly as a result of having emerged on the side of a dune (see below).

Features such as small-scale terraces, channelized-flow features, and coated grains (e.g., Keppel et al. 2011), which can also be found in subaerial spring mounds, were not noted. The lack of channelized-flow features may indicate that the emergent spring waters were always saturated with respect to carbonate. For example, Keppel et al. (2011; see also Roberts and Mitchell 1987) observed these features in a spring mound in the Great Artesian Basin of Australia, but noted that the channelization resulted from undersaturation of the waters in the central pool of the spring. The carbonate mound at site 1 did not have a central pool, nor has this kind of feature been observed in any of the Navajo Sandstone carbonate mounds (Parrish et al. 2017).

Interpretation of the two middle intervals of the carbonate mound is limited by the silicification. The cause of silicification of these parts of the mound is unclear, but is unlikely to have been a change to hydrothermal waters, for two reasons. First, this is the only mound with extensive silicification (Parrish et al. 2017), and a change to hydrothermal fluids would be unlikely to affect only one of the more than 200 mounds documented to date, including several less than a half-kilometer away that are also correlative with the middle carbonate unit; in addition, the last part of mound deposition was carbonate rock. Second, no evidence exists that the carbonate mounds in the Navajo Sandstone are related to underlying structures that would be conduits for hydrothermal fluids. Where the mounds do occur in lineaments, which is not the case at either site in this study, the trends are inconsistent with the underlying structures (Parrish et al. 2017). The upper middle interval is also characterized by in situ brecciation consistent with weathering. Although it would be highly unusual, it is possible that the chert is a form of silcrete. We interpret the 


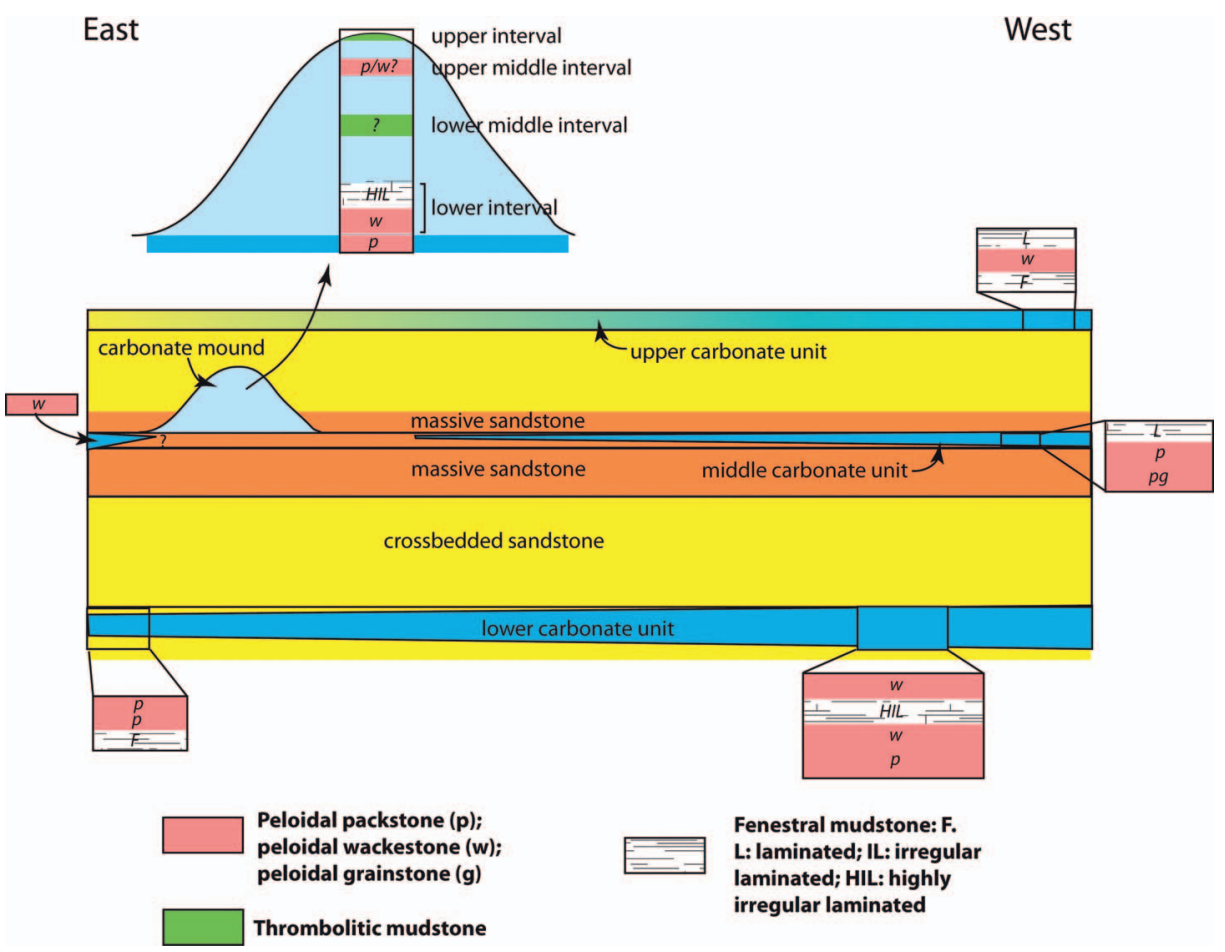

FIG. 9.- Schematic diagram of site 1 showing the distribution of facies, illustrated in boxes around the diagram and on the blow-up of the carbonate mound in the upper left; other colors are the overall lithologies of the beds, and the graded color for the upper carbonate unit indicates that it grades into sandstone with carbonate clasts near the mound (see also Fig. 7). The peloidal wackestone and the overlying highly irregular laminated fenestral mudstone from the lower part of the mound are from the inner and outer parts of the lower mound interval (see Fig. 10). The question marks in the facies of the mound refer to samples 018 and 019 , which are mixed chert and clastics that appear to replace thrombolitic or peloidal pack-wackestone, respectively (see Supplemental Table 1). The question mark in the middle carbonate under the mound refers to the possibility that this carbonate extends under the mound. Not to scale; tufa mound is $4 \mathrm{~m}$ high.

breccia in the upper middle interval to mean that flow down the sides of the mound ceased briefly at times, enough to allow short-term desiccation and weathering of the surface. The brecciation is thin $(<1 \mathrm{~mm}$ thick $)$, indicating that flow, along with the associated precipitation of calcite, resumed almost as soon as it had ceased.
The top of the mound (upper interval) has a brecciated central area surrounded by smooth rock. Parrish et al. (2017) interpreted this morphology as indicating spring vents. The rock is dolomite with minor calcite as late-stage pore fill and is mostly recrystallized; remnant fabric is thrombolitic mudstone. No evidence for penecontemporaneous weathering

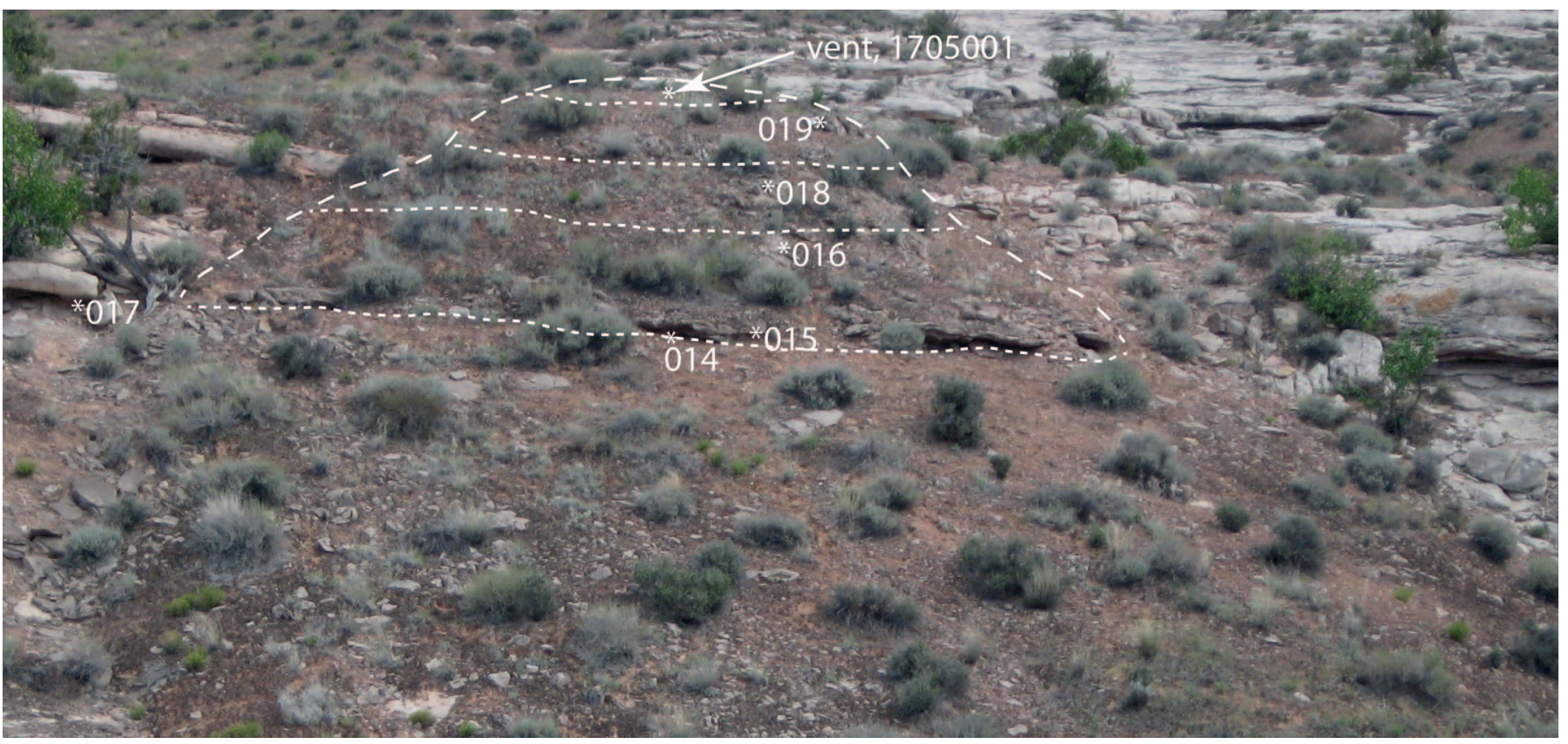

FIG. 10.-Photograph of the tufa mound at site 1. Stars, sample sites with sample numbers. Long-dashed line, approximate outline of the carbonate mound. Short-dashed lines demarcate intervals within the carbonate mound. Note that the bed represented by sample 015 appears to be stratigraphically lower than the one represented by 017 ; this is because the lower interval in the carbonate mound inclines toward the reader (north). The surface visible between 015 and 016 is the drape of the lower interval; 015 is from the inner part of this drape, and 016 from the outer part. This inclination is primary and $30^{\circ}$; the regional dip is $<5^{\circ}$ to the north. Height from 014 to the vent is $\sim 4 \mathrm{~m}$. 


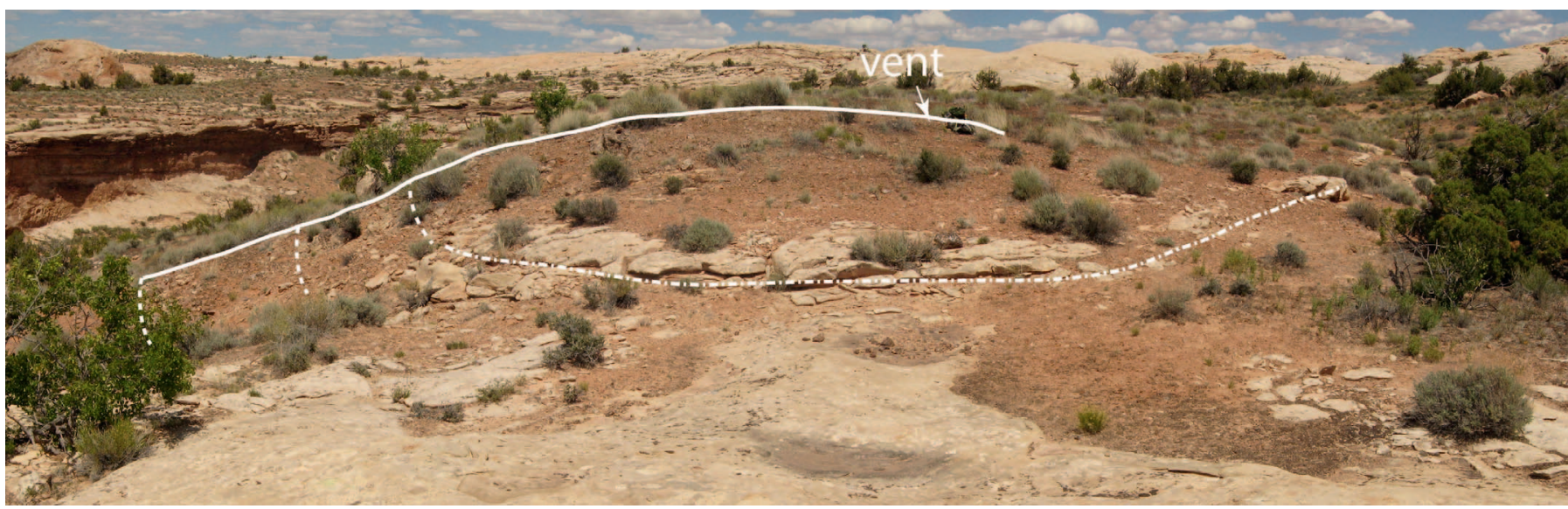

FIg. 11.-Profile of tufa mound at site 1, looking east. The carbonate mound does not crop out on the south side (right), even though the slope is about the same as that to the north. Rather, the beds on that side are sandstone. Solid line, upper surface of exposed mound; dashed lines, intervals as in Figure 10; dash-dot line, lower boundary of a sandstone bed that borders the upper part of the mound on the south (opposite side of mound from Fig. 10).

at the top of the mound was observed, suggesting that the spring was overtaken and terminated by dune migration.

The geometry of the sandstone beds surrounding the tufa mound suggests the possibility that the spring emerged on the side of a large dune. The lower part of the mound is bounded by nearly identical sandstone beds, and the sandstone beds coinciding with the upper part of the mound form a wedge. In profile, the exposed intervals on the north side of the mound appear to be contiguous with sandstone beds on the south side, even though the slope profiles are about the same (Fig 11). Emergence of the spring on the side of a dune might explain why the mound is possibly contiguous with the middle carbonate unit only to the east. Alternatively, the mound formed and was subsequently overtaken by a dune; if that had been the case, the mound would have been a prominent feature in the landscape.

\section{Field Descriptions and Relationships-Site 2}

Description.- Site 2 (Fig. 1) consists of a single carbonate unit that is partially contiguous with a carbonate mound. The upper surface of the carbonate deposit is exposed near the mound but is covered elsewhere, and the underlying sandstone bed is exposed over a thickness of $<2 \mathrm{~m}$ before disappearing into cover. The 1.3-m-thick carbonate mound is well exposed in cross section and has three discernible intervals within it (Fig. 12). The facies are illustrated in Figure 13; specific observations are provided below.

Several thin carbonate and sandstone beds underlie the mound. These overlie massive sandstone at the base of the section. These beds are bowed downward under the mound (Fig. 12). The lowest and next highest are separated by a thin, silty, very fine sandstone. Their descriptions, from the lowest of these carbonate beds to the highest, are in Table 4. The facies in the carbonate beds, the carbonate unit, and the mound intervals are illustrated in Figure 13. The middle interval of the mound pinches out beneath the upper interval just east of the mound (left in Figs. 12, 13) and continues in that direction as a prominent break in sedimentation of the carbonate unit; it is truncated by erosion on the south. The upper interval is draped over the underlying intervals (Fig. 12). The bioclastic grainstone in the middle of the upper interval contains ostracodes and a small $(10 \mathrm{~mm})$ valve of a pelecypod with simple ornamentation (Fig. 5C); geopetal features and ooids are also present (Supplemental Table 1).

Intervals in the mound grade laterally into flat-lying carbonate beds to the east (Fig. 13). The lower mound interval continues to the east and is traceable into two beds, a charophyte-bearing bed overlain by a bed with ostracodes and circumgranular cracking. The upper vuggy, massive interval of the mound grades into several thin, subparallel, continuous beds with ostracodes. The lower sample from this part of the unit has circumgranular cracking; the upper sample has a burrow and a mudcrack. The uppermost bed in the carbonate unit east of the mound has charophytes and circumgranular cracking.

South of the mound, the preserved carbonate unit is apparently correlative with the thin carbonate beds that underlie the tufa mound (Fig. 13). However, a critical area between the mound and the adjacent carbonate unit is partially obscured, and it is not possible to trace the beds precisely (Figs. 13, 14). We were unable to determine whether the thrombolitic mudstone in the carbonate unit was contiguous with the mound (Fig. 13); this bed has circumgranular cracking, charophytes, and ostracodes.

Conifer stumps breach the carbonate unit, which is upturned around the stumps (Fig. 13; Parrish and Falcon-Lang 2007, their Fig. 8B). The lower part of the upturned beds has ostracodes, charophytes, plant debris, fecal pellets, and $10-25 \%$ quartz grains; the overlying peloidal packstone has ostracodes, charophytes, and fecal pellets, and is sandier, about $40 \%$ quartz grains. The trees are clearly rooted in the underlying sandstone (Parrish et al. 2017). The carbonate unit continues to the south and changes character (Fig. 13); ostracodes are found throughout.

It should be noted that four carbonate units formed in this area. The carbonate unit and mound studied here were the highest stratigraphically; tufa mounds also are found in the second-highest carbonate unit at this site.

Interpretation.-The history of the carbonate deposit at site 2 commences with deposition of sandstone that became wet enough to support trees; groundwater was emergent in a small depression nearby, forming a lake. This lake must have been very localized at this site. Although the downward bowing of the initial lake beds under the mound is likely at least partially due to the weight of the tufa mound that subsequently formed, there must also have been some primary topography at this site, because the lowest limestone bed cannot be traced laterally, and the next highest limestone bed can be traced only to the east, suggesting that these formed in a pre-existing low spot. This depression may have been an arm of a larger lake, a conclusion supported by the presence of a fish scale and a lack of features indicating drying. Frederickson and Davis (2017) concluded that fish in the Navajo Sandstone lived in waters that were "deep," but provided no specific depth estimate.

The lake level rose and the lake expanded. This interpretation is supported by the southward extension of some of the carbonate beds, where the water drowned and deposited carbonate around trees. No 


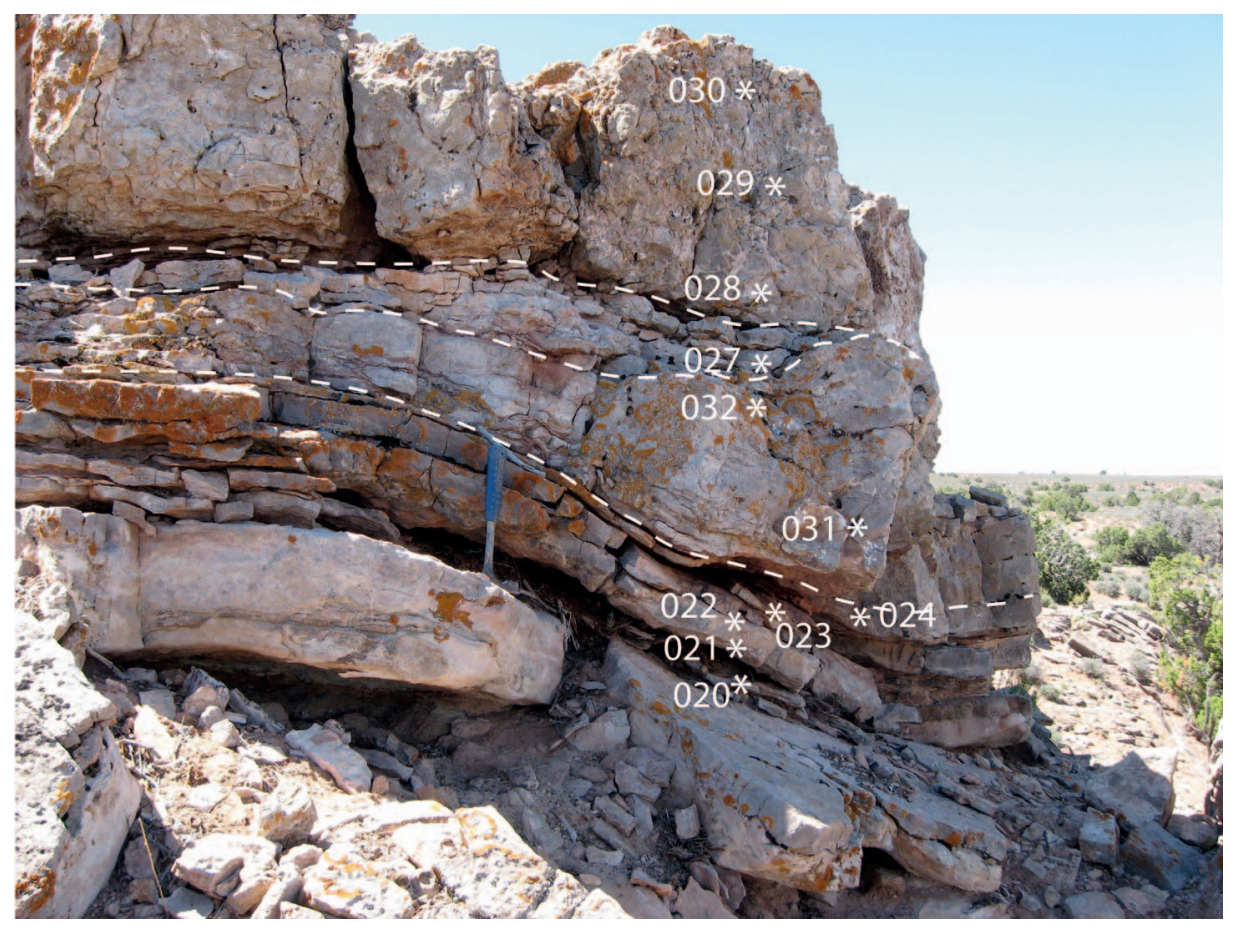

FIG. 12.-Carbonate mound at site 2. Stars, sample locations with sample numbers; dashed lines delineate the lower, middle, and upper intervals in the mound. The photograph shows the north-facing side of the erosional exposure; the west-facing side is around the corner on the right side of the photo (see Fig. 13). Note the distinct downward-bowing, to the right, of the beds below the mound. Hammer $28 \mathrm{~cm}$.

evidence of drying is present in the equivalent beds to the east, supporting the interpretation of lake expansion at this time. Only the thrombolitic mudstone proximal to the mound shows evidence of drying, suggesting localized exposure.

The rise in lake level may have resulted from groundwater seepage or onset of the spring flow that eventually built the mound (as well as other mounds nearby; Parrish et al. 2017). The mound experienced at least three phases of growth. The middle massive, vuggy interval likely represents a period of reduced spring flow because it does not extend beyond the mound itself, whereas the lower and upper intervals grade eastward into lacustrine carbonate. The middle interval correlates with a prominent break in sedimentation in the adjacent carbonate unit. A cessation or reduction of spring flow is supported by circumgranular cracking in the top of the carbonate bed immediately preceding this break in sedimentation.
The bioclastic grainstone in the middle of the upper interval is not readily explained. Except for charophytes, no other sample from the mound contains fossils, and this unique sample also contains the only pelecypod, ooids $(<100 \mu \mathrm{m}$ in diameter), and geopetal structures found thus far. The contiguous lake bed lacks ooids and is mudcracked. The underlying thrombolitic mudstone in the mound has millimeter-scale breccia clasts that might indicate higher-energy flow, as suggested by the ooids above, but the contiguous lake bed has circumgranular cracking. Much more detailed sampling would be required to explain the history of this part of the upper interval.

Figures 13 and 14 illustrate an additional unresolved anomaly in the depositional pattern of the carbonate deposit at site 2 . The lacustrine carbonate beds to the south are lateral equivalents of those underlying the tufa mound, and possibly of the lowest part of the lowest mound interval,

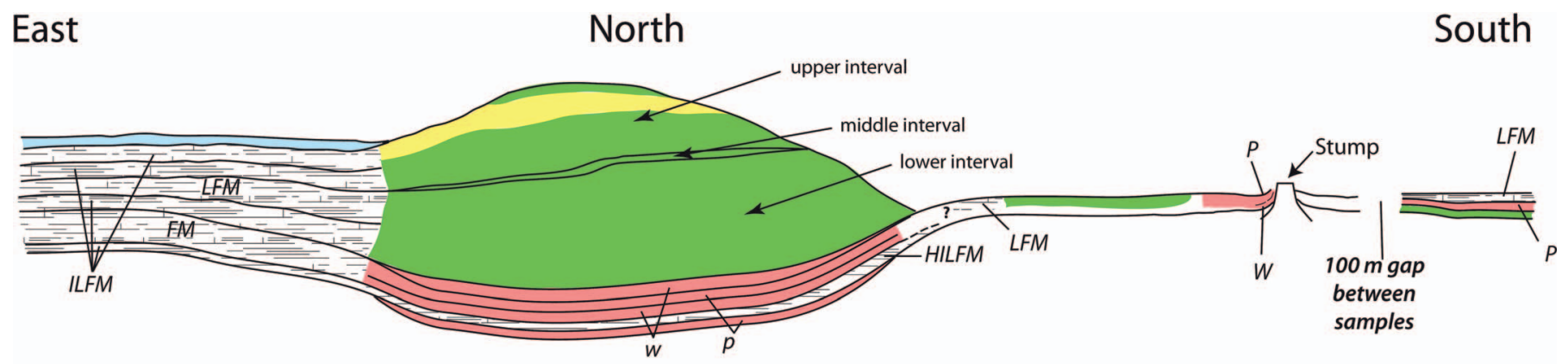


TABLE 4.-Facies in thin carbonate beds underlying tufa mound at site 2. Beds are numbered from bottom (1) to top (5).

1 Sandy peloidal packstone; $30-50 \%$ quartz grains, dispersed and in lenses; charophytes, ostracodes, and a fish scale. Bed pinches out or is covered in both directions from mound.

2 Highly irregularly laminated fenestral mudstone; $30 \%$ quartz grains, dispersed and in lenses; ostracodes and vascular plant fragments. Bed cannot be traced to the south, but is contiguous with carbonate unit to east, where it grades laterally into irregularly laminated fenestral mudstone that forms the lowest bed of the carbonate unit in that direction.

3 Peloidal wackestone, $<5 \%$ quartz grains, ostracodes, and charophytes. Bed contiguous with beds in the carbonate unit to east and, possibly, to south. To east, traced into lower part of a fenestral mudstone; to south, most likely correlative with lower part of laminated fenestral mudstone.

4 Peloidal packstone, $10 \%$ quartz grains, ostracodes. Bed traced into the upper part of fenestral mudstone east of mound and to upper part of thrombolitic mudstone south of mound.

5 Peloidal wackestone, 5-10\% quartz grains, no fossils observed. Bed lenticular, confined to area under mound.

whereas the lacustrine carbonate beds to the east include beds that are equivalent to most of the tufa mound. Erosion and cover prevent resolution of the southward extension of the tufa-mound-equivalent lacustrine carbonate beds (Parrish et al. 2017). It is possible that a dune covered part of the lake before spring flow started, so that the emerging waters flowed only east, but this is entirely speculative.

In summary, the history at this site is deposition in an interdune lake that extended to the south from the location of the tufa mound and partially to the east. This lake experienced episodic influxes of sand. The lake surrounded and drowned trees and, away from the location of the tufa mound, ended with weathering of the carbonate beds with exposure. Subsequently, a spring formed and lacustrine deposition recommenced, but to the east. This lake experienced brief lowstands.

\section{DISCUSSION}

The flat-lying carbonate units in the Navajo Sandstone represent interdune lakes (e.g., Stokes 1991; Bromley 1992; Eisenberg 2003; Parrish and Falcon-Lang 2007; Parrish et al. 2017). The source of the water is generally agreed to be mostly groundwater, but two different mechanisms for the delivery of groundwater to the surface have been invoked, intersection of the water table with the ground surface, creating lakes by seepage, or delivery of water to the lakes by artesian springs. Groundwater seepage was suggested by Stokes (1991) and Bromley (1992); neither reported a carbonate mound. Eisenberg's (2003) interpretation was similar; he referred to the carbonate beds as shallow (undefined) lakes developed through subsurface drainage from eastern highlands (the Uncompahgre uplift) and rainwater runoff from monsoonal precipitation. Eisenberg (2003) further concluded that the lakes were dammed behind terminal dunes, and that the carbonate mounds are giant stromatolite mounds. In contrast, Parrish and Falcon-Lang (2007) agreed that the source of the water was likely the Uncompahgre uplift, but interpreted the carbonate beds as spring-fed lakes and the carbonate mounds as artesian-spring deposits, i.e., tufa mounds. Parrish and Dorney (2009) and Parrish et al. (2017) noted that both processes could be at play. The interpretation of the carbonate mounds in the Navajo Sandstone, then, is controversial: Were they spring deposits (sublacustrine or subaerial), or were they sublacustrine stromatolite mounds? If the former, were they ambient-temperature springs or hydrothermal springs?

The analysis of these mounds is inhibited by the lack of modern analogs for subaerial, tufa-mound-depositing artesian springs (Pentecost 2005; Della Porta 2015). Although modern tufa is abundant and well studied, nearly all the literature focuses on fluvial tufa, i.e., cascades, barrages, and dams, or on mounds in saline-alkaline lakes, which may or may not have formed subaerially (e.g., Benson 1994). Few freshwater, subaerial, ambient-temperature modern spring mounds have been studied in detail, especially with respect to the petrography, and none that are associated with lakes. To our knowledge, the only modern spring mounds that have received the kind of treatment that allows direct comparison of facies are those in the Great Artesian Basin (Keppel et al. 2011; see section on Petrography and Facies). Most studies have focused solely on the chemistry of the carbonate, particularly as it relates to the chemistry of the waters that flow from the springs and to alteration by human activity (e.g., Mudd 2000; Fensham and Fairfax 2003; Valero Garcés et al. 2008; Swanson et al. 2014; Dabkowski et al. 2015a).

In older deposits, the petrographic study most comparable to ours is that of Nicoll and Sallam (2016). Among the microtextures reported by them are clotted textures, peloids and oncoids, microlaminations, fenestral pores, recrystallization, and mantles of dust, all of which are similar to those reported here. However, the tufa studied by them was fluvial and had other textures not observed in the Navajo Sandstone carbonate deposits, including arborescent shrub forms, domal stromatolites, textures created by macroscopic plants, and fibroradial crystals forming fans or crusts. The latter are of particular interest in the context of this study, and is discussed further below.

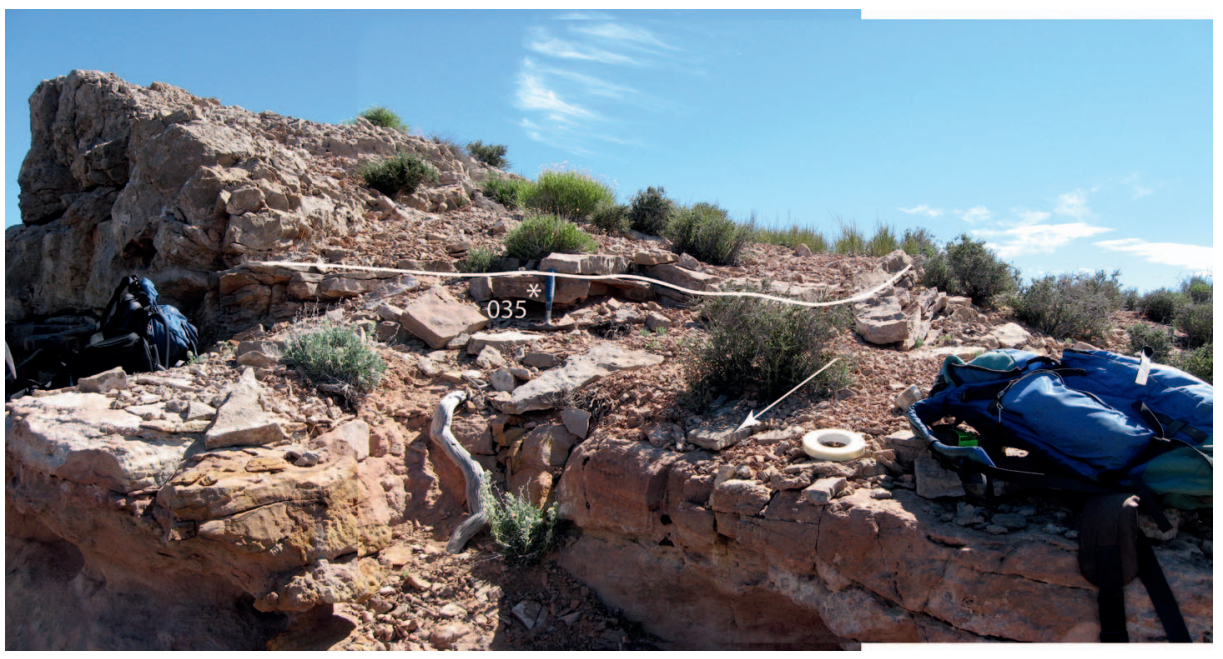

FIG. 14.-Carbonate mound at site 2 and correlative carbonate on the west-facing side; top of mound in upper left. Solid white line traces the undulatory upper surface of the carbonate that is correlative to the beds represented by samples 022 and 023 in Figure 12. The carbonate bed (arrow) also inclines slightly toward the reader; this undulatory shape reflects original topography on top of the sandstone; to the right, the line tracing the top of the bed turns up over a tepee structure. Sample 035 location provided for reference to Supplemental Figure 2. Hammer (near sample 035) $28 \mathrm{~cm}$. Composite photo; camera angles did not permit a seamless pan, and there is a seam about one-third of the way from the left of the photo. 
In the following, we discuss whether the tufa mounds in the Navajo Sandstone were subaerial springs, then address the question of whether they were hydrothermal springs or ambient-temperature springs.

\section{Navajo Sandstone Carbonate Mounds as Subaerial Springs}

To our knowledge, there has never been a comprehensive comparison of stromatolite mounds and tufa mounds. As pointed out by Parrish et al. (2017), this may be partly because the distinction is somewhat artificial, as microbial influence is certainly present in nearly all carbonate deposition (e.g., Calvo et al. 1989; Freytet and Verrecchia 2002; Shiraishi et al. 2008; Casado et al. 2014; García Del Cura et al. 2014; Della Porta 2015) and may be required for carbonate deposition in freshwater systems (Rogerson et al. 2008).

With a few exceptions (especially some of the petrographic textures in hydrothermal deposits, see below), no characteristic or even set of characteristics is strictly diagnostic of nonmarine carbonate rocks (Jones and Renaut 2010; Della Porta 2015), which is one of the reasons they are so resistant to classification (e.g., Jones and Renaut 2010). Regardless, some associations more commonly occur in some types of mounds than others. For this discussion, a distinction must be made between stromatolite mounds (also called bioherms) and spring mounds, both of which are microbially influenced (Della Porta 2015). Stromatolite mounds are sublacustrine; generally are on the scale of meters or less; have peloidal, packstone, and laminated fabrics, ooids, and intraclasts; and, most importantly, have columnar, cylindrical, domal, and/or inverted cone structures overlying tabular thin beds of peloidal wackestone and packstone with ostracodes. They are not layered, and multiple mounds are arrayed parallel to shoreline (Della Porta 2015). The best-studied ancient examples are from the Eocene Green River Formation (e.g., Sarg et al. 2013; Awramik and Buchheim 2015); caddisfly mounds there also include laminated, columnar microbialites that are typical of lake-margin bioherms (Leggitt and Cushman 2001; Leggitt et al. 2007). These features are not found in the Navajo Sandstone tufa mounds.

Spring mounds and pinnacles can be tens of meters high, are usually fault controlled, are produced by groundwater and/or hydrothermal fluids, and are layered; most examples formed in sublacustrine environments (Della Porta 2015), although they may remain constructional even after exposure (Benson 1994; Guo and Chafetz 2012, 2014). The best-studied examples of these types of mounds are tufa mounds in the saline-alkaline lakes of the western U.S., including Pyramid and Searles lakes. These consist of laminated, columnar, concentric, pillowed, and other internal and external structures (Scholl 1960; Benson 1994; Guo and Chaftez 2012) that are not found in the Navajo Sandstone mounds. Reported spring mounds in the Green River Formation also have internal structuresupward-branching digitate structures and downward-branching "arborescent" growth with banding and silica cement - that do not resemble any features in the Navajo Sandstone mounds (Seard et al. 2013).

Overall, the tufa mounds in the Navajo Sandstone bear little resemblance to either stromatolite bioherms or sublacustrine spring mounds as categorized by Della Porta (2015) and observed in the Green River Formation and the saline-alkaline lakes of the western U.S. In addition, such features as channelized flow and central spring pools, characteristic of the carbonate mounds of the Great Artesian Basin (Keppel et al. 2011), are also lacking in the Navajo Sandstone mounds.

Some stromatolitic bioherms and nearly all spring mounds observed today are associated with saline-alkaline lakes. Although Riding (2011) suggested that this association is necessary, this may not be strictly true. For example, it is not clear what the water chemistry was when the tufa mounds in Pyramid and Searles Lake formed; they formed at highstands, and, although the lake apparently remained closed during those highstands, the water presumably was fresher (Benson 1994). The same is true of the stromatolites in the Green River Formation (Graf et al. 2015; Rhodes and
Carroll 2015). In the Navajo Sandstone, although very late stages of some of the interdune lakes were clearly saline (e.g., the lower carbonate unit at site 1 and others reported by Parrish et al. 2017), there is no evidence that the lakes were anything other than freshwater or slightly alkaline when the tufa mounds were forming and before the lakes completely desiccated. In addition, preliminary isotopic analyses reported by Parrish and Dorney (2009) indicate that the waters fell in the range of groundwaters from modern freshwater, ambient-temperature carbonates, ranging from $0 \%$ to $-14 \%$ o $\delta^{18} \mathrm{O}_{\mathrm{VMSOW}}$ (see, for example, Ibarra et al. 2014).

The Navajo Sandstone tufa mounds in this study are composed mostly of thrombolitic mudstone. Thrombolite is generally associated with marine rocks (e.g., Pratt and James 1982; Kennard and James 1986; Schmid 1996). Whether there is an environmental significance to the deposition of thrombolite as opposed to stromatolite has, to our knowledge, not been explored in depth. Stromatolite and thrombolite often occur together; Kennard and James' (1986, their Fig. 6) ternary classification diagram comprised the end members thrombolite ("mesoclots"), stromatolite ("stromatids"), and what would now be called leiolite (cryptomicrobial fabrics), with gradational structures in between. Kennard and James (1986), noting that (at the time) thrombolite was known mainly from the early Paleozoic, attributed the difference in morphology to evolution of the microbial communities. Schmid (1996), who modified Kennard and James' (1986) classification to include pelodial microstructures, attributed the difference partly to water energy and sedimentation rate, but as his scheme was for marine microbialites, it is not clear whether it would apply to freshwater tufa. As petrographic studies of more Navajo Sandstone tufa mounds proceed, the significance of thrombolite in these structures may become clearer.

In addition to the lack of structures consistent with sublacustrine precipitation, field relationships show that the Navajo Sandstone tufa mounds were unlikely to be sublacustrine. We cannot entirely rule out submergence of the mound at site 2, although the evidence is contradictory. The mound at site 1, however, might have been sublacustrine only in its earliest stages, although the laterally equivalent lacustrine carbonate is thin and may have preceded mound formation. That most of this mound is surrounded by sandstone deposited in dunes indicates that it was a positive, subaerial feature on the landscape during or before deposition of the dune sandstone.

A broader survey of carbonate mounds in the Navajo Sandstone did not reveal shoreline-parallel patterns, and some carbonate mounds in the Navajo Sandstone are not associated with lakes at all but are surrounded entirely by sandstone (Parrish et al. 2017). Evidence of weathering indicates that the mounds were exposed for periods of time. Although this would occur if sublacustrine mounds were exposed by drops in lake level, weathering could also indicate times of lower spring flow in a persistently subaerial mound.

Another line of evidence that the Navajo Sandstone spring mounds were subaerial is the contiguity of some of the mound intervals with adjacent lake beds. Springs that emerge underwater deposit carbonate immediately and rapidly, allowing the rapid formation of pinnacles (Rosen et al. 2004). By contrast, water emerging subaerially would deposit carbonate in drapes like the ones observed in the Navajo Sandstone mounds and, with sufficient water flow, these drapes would extend to the adjacent lake waters and merge with the carbonate beds forming in the lakes. The lateral gradation of most of the mound at site 2 into adjacent lacustrine carbonate beds supports this interpretation.

For completeness, we note that both interpretations of the carbonate mounds in the Navajo Sandstone - as spring mounds or stromatoliteswere rejected by Wilkens (2008), who described small carbonate mounds as "decay-induced collapse of cycadeoid gymnosperms," an explanation subsequently accepted by Parrish et al. (2017) for small-scale $(<1 \mathrm{~m}$ diameter), chert-cored mounds. Wilkens (2008) argued that the larger mounds are large-scale tepee structures, a description that bears no 
relationship to the carbonate mounds described here and elsewhere in the Navajo Sandstone. Although tepee structures are present, they are linear features and lack the brecciated cores present in the tufa mounds (Parrish et al. 2017).

We conclude that the preponderance of evidence-vuggy texture, lack of biohermal structures, weathering, draping, and lateral relationships to lacustrine carbonate and sandstone-favor an interpretation that the mounds in this study were formed subaerially by springs. In addition, although the tops of the mounds in this study were not preserved, many other mounds in the Navajo Sandstone have distinct vents of fractured carbonate rock, as well as the draped sides that are present in the mounds at sites 1 and 2, further evidence that the mounds formed subaerially. The next question, then, is whether or not the springs were hydrothermal.

\section{Ambient-Temperature Springs Versus Hot Springs}

If the carbonate mounds in the Navajo Sandstone are springs, the question arises whether they were deposited in ambient-temperature springs or hot springs, which relates to the terminology that we chose. Both tufa and travertine have been used for mound-shaped, nonmarine carbonate rocks (e.g., Pentecost and Viles 1994; Ford and Pedley 1996; Pentecost 1996, 2005; Jones and Renaut 2010; Della Porta 2015). The terms are often used interchangeably (Viles and Goudie 1990); some, but not all, workers use travertine to describe carbonate deposits formed in hydrothermal waters (thermogene of Pentecost and Viles 1994) and tufa to deposits formed in ambient-temperature (i.e., shallow groundwater) springs, streams, or shallow water bodies (Pedley 1990; meteogene of Pentecost and Viles 1994; see also Ford and Pedley 1996; Pentecost 1996; Capezzuoli et al. 2014; Della Porta 2015; but see also Pentecost 2005). The problem with this classification is that it depends on knowing the temperature and chemical composition of the waters, which cannot be easily measured in the geologic record and is especially challenging to determine for meteoric waters, given the wide range of influences on water chemistry, including original isotopic composition, postdepositional fractionation, salinity, alkalinity, and mixing of ambient-temperature groundwater with hydrothermal water. As noted above, even more challenging for understanding the mounds in the Navajo Sandstone is that modern analogs for subaerial, ambient-temperature spring mounds are rare (Pentecost 2005; Della Porta 2015).

Attempts to classify tufa texturally have also been problematic (Pentecost 2005; Jones and Renaut 2010; Della Porta 2015), but texture remains the best method for distinguishing between the two types of deposits in the older geologic record. Hot-spring travertine typically consists of buildups that are a centimeter to tens of meters thick and meters to kilometers wide (Pentecost 2005; Della Porta 2015). Fabrics are typically clotted peloidal, leiolitic, crystal fan, isopachous, and microcolumnar (Pope and Grotzinger 2000; Jones and Renaut 2010; Della Porta 2015; but see, for example, Ibarra et al. 2014), and commonly include dendritic crystals, "feathers," and "cone-in-cone" crystallization (Pentecost 2005). Nicoll and Sallam (2016) found fan-like crystallization in the fluvial tufa they studied at Kurkur Oasis, but they interpreted this structure as recrystallization of micrite and unrelated to water temperature. In addition to having textures not found in tufa mounds, travertine deposits are typically fault controlled and may overlap with episodes of magmatism (Pentecost 2005; Priewisch et al. 2014; Della Porta 2015).

We reject the hypothesis that the carbonate mounds in the Navajo Sandstone are hydrothermal. Although the clotted peloidal and leiolitic fabrics seen in some hydrothermal deposits also occur in the Navajo Sandstone tufa mounds, those fabrics are found in most nonmarine (and many marine) carbonate rocks, and none of the other fabrics characteristic of hydrothermal deposits occurs in the Navajo Sandstone. Moreover, the sizes and morphologies of the carbonate mounds in the Navajo Sandstone are inconsistent with well-developed hydrothermal deposits, which exhibit large-scale terracing, although this is not diagnostic, as some hydrothermal mounds are superficially similar in size, shape, and texture to the ones in the Navajo Sandstone (e.g., Crossey et al. 2011; Priewisch et al. 2014). In addition, although ostracodes and charophytes can tolerate higher-thanambient temperatures, other aspects of the biota are inconsistent with a hydrothermal origin for the waters, particularly the pelecypod and the possible sponge. The trees that grew immediately before the formation of the lake and the fish that lived in the early stages of the lake that preceded the mound at site 2 would not have been able to tolerate hot waters, so if the mound had been hydrothermal, that would have required influx of hot waters into the cool waters of a lake formed by groundwater seepage. No evidence exists that would support a large change in temperature, and preliminary oxygen isotope data on both mound and lake deposits show that the lake carbonate is only slightly enriched in ${ }^{18} \mathrm{O}$ compared to the mound carbonate (a mean of $-6.9 \%$ for the mounds versus $-5.9 \%$ for the lakes), by an amount that is explained by evaporation (Dorney and Parrish 2009).

\section{CONCLUSIONS}

Carbonate deposits in the Navajo Sandstone consist of interdune lacustrine deposits associated with tufa mounds. Flat-lying, bedded carbonate units are interdune lakes. Although the tufa mounds resemble none reported in the literature, the preponderance of evidence is that the tufa mounds were constructed subaerially by ambient-temperature springs. This evidence includes:

1. Microbial fabrics;

2. Vuggy porosity;

3. Weathered surfaces;

4. Biota in and near the mounds inconsistent with hydrothermal temperatures;

5. Absence of columnar, domal, cylindrical, or other micro- or mesostructures consistent with stromatolitic bioherms;

6. Absence of crystal fan, "feather," isopachous, and other textures typical of hydrothermal mounds;

7. Association with lake deposits that are contiguous with the mound carbonates;

8. Draped intervals;

9. Wind-blown sand adhering to the mound surfaces;

10. Topographic relief above the level of the lake carbonate beds.

Both springs and lakes dried episodically during deposition before being terminated by cessation of groundwater flow and/or migration of eolian sand dunes through the interdune.

The carbonate deposits in the Navajo Sandstone, particularly the tufa mounds, do not closely resemble deposits reported from modern or other ancient settings. This may be more a result of a lack of equivalent studies on interdune carbonate deposits than uniqueness of the Navajo deposits. More petrographic work on interdune carbonates of all types should help illuminate their complexity and significance.

\section{SUPPLEMENTAL MATERIAL}

Supplemental files are available from JSR's Data Archive: http://sepm.org/ pages.aspx?pageid $=229$.

\section{ACKNOWLEDGMENTS}

We thank Dr. Michael C. Pope, Texas A\&M University, for his invaluable help with the petrographic analyses and loan of a microscope and lab space for the initial analysis. The first author thanks USN Capt. W.S. Ryder for allowing him to dedicate all his efforts to completing his MS thesis, and for his generosity and hospitality, and the United States Navy for providing the opportunity to attend college and extend the allotted time to allow pursuit of an 
MS degree. We are grateful to Dr. Ronald Blakey and his wife, Dee, for their hospitality and his advice and to Dr. Fred Peterson and Dr. Christine Turner for their help and advice. Two anonymous reviewers and Associate Editor Dr. Kathleen C. Benison provided immeasurable help in improving this manuscript. This work was supported in part by the University of Idaho and completion of the work was partially supported by National Science Foundation EAR1349560 to Parrish, EAR 1349564 to Chan, and EAR 134956 to Hasiotis. The work was partially accomplished under Bureau of Land Management Permit \#UT15-14S to STH.

\section{REFERENCES}

AITKEN, J.D., 1967, Classification and environmental significance of cryptalgal limestones and dolomites, with illustrations from the Cambrian and Ordovician of southwestern Alberta: Journal of Sedimentary Petrology, v. 37, p. 1163-1178.

ALONSO-ZARZA, A.A., 2003, Palaeoenvironmental significance of palustrine carbonates and calcretes in the geological record: Earth-Science Reviews, v. 60, p. 261-298.

Arenas-Abad, C., Vázquez-Urbez, M., Pardo-Tirapu, G., and Sancho-Marcén, C., 2010, Fluvial and associated carbonate deposits, in Alonso-Zarza, A.A., and Tanner, L.H., eds. Carbonates in Continental Settings: Facies, Environments and Processes: Amsterdam, Elsevier, Developments in Sedimentology 61, p. 133-175.

Arp, G., Hofmann, J., And Reitner, J., 1998, Microbial fabric formation in spring mounds ("microbialites") of alkaline salt lakes in the Badain Jaran sand sea, PR China: Palaios, v. 13 , p. $581-592$.

Averitt, P., Wilson, R.F., Detterman, J.S., Harshbarger, J.W., and Repenning, C.A., 1955, Revision in correlation and nomenclature of Triassic and Jurassic formations in southwestern Utah and northern Arizona: American Association of Petroleum Geologists, Bulletin, v. 39, p. 2515-2524.

Awramik, S.M., and BuchHeim, H.P., 2015, Giant stromatolites of the Eocene Green River Formation (Colorado, USA): Geology, v. 43, p. 691-694.

BAKER, A.A., 1936, Geology of the Monument Valley-Navajo Mountain region, San Juan County, Utah: U.S. Geological Survey, Bulletin 865, 106 p.

Benavente, C., Mancuso, A., Cabaleri, N., and Gierlowski-Kordesch, E., 2015, Comparison of lacustrine successions and their palaeohydrological implications in two sub-basins of the Triassic Cuyana rift, Argentina: Sedimentology, v. 62, p. 1771-1813

Benson, L., 1994, Carbonate deposition, Pyramid Lake subbasin, Nevada: 1. Sequence of formation and elevational distribution of carbonate deposits (Tufas): Palaeogeography, Palaeoclimatology, Palaeoecology, v. 109, p. 55-87.

Blakey, R.C., 2008, Pennsylvanian-Jurassic sedimentary basins of the Colorado Plateau and southern Rocky Mountains, in Miall, A.D., ed., Sedimentary Basins of the United States and Canada, Volume 5: Burlington, Elsevier, p. 245-296.

Blakey, R.C., Peterson, F., and Kocurek, G., 1988, Synthesis of late Paleozoic and Mesozoic eolian deposits of the Western Interior of the United States: Sedimentary Geology, v. 56 , p. $3-125$

Bosence, D., Gibbons, K., Le Heron, D.P., Morgan, W.A., Pritchard, T., and Vining, B.A. 2015, Micriobial carbonates in space and time: Introduction, in Bosence, D., Gibbons, K., Le Heron, D.P., Morgan, W.A., Pritchard, T., and Vining, B.A., eds., Microbial Carbonates in Space and Time: Implications for Global Exploration and Production: Geological Society of London, Special Publication 418, p. 1-15.

Brehm, U., Gorbushina, A., And MotTershead, D., 2005, The role of microorganisms and biofilms in the breakdown and dissolution of quartz and glass: Palaeogeography, Palaeoclimatology, Palaeoecology, v. 219, p. 117-129.

Bromley, M., 1992, Topographic inversion of early interdune deposits, Navajo Sandstone (Lower Jurassic), Colorado Plateau, USA: Sedimentary Geology, v. 80, p. 1-25.

Brook, G.A., BuRney, D.A., AND CowarT, J.B., 1990, Desert paleoenvironmental data from cave speleothems with examples from the Chihuahuan, Somali-Chalbi, and Kalahari deserts: Palaeogeography, Palaeoclimatology, Palaeoecology, v. 76, p. 311-329.

Ввооке, B., 2001, The distribution of carbonate eolianite: Earth-Science Reviews, v. 55, p. $135-164$.

BRooKFIELD, M.E., 1977, The origin of bounding surfaces in ancient aeolian sandstones: Sedimentology, v. 24, p. 303-332.

Buis, G.J., Goldstein, R.H., Hasiotis, S.T., and Rogers, J.R., 2004, Preservation of microborings as fluid inclusions: Canadian Mineralogist, v. 42, p. 1563-1581.

Cabaleri, N.G., AND Benavente, C.A., 2013, Sedimentology and paleoenvironments of the Las Chacritas carbonate paleolake, Cañadón Asfalto Formation (Jurassic), Patagonia, Argentina: Sedimentary Geology, v. 284-285, p. 91-105.

Cabaleri, N.G., Benavente, C.A., Monferran, M.D., Narváez, P.L., Volkheimer, W., Gallego, O.F., and Do CAmpo, M.D., 2013, Sedimentology and palaeontology of the Upper Jurassic Puesto Almada Member (Cañadón Asfalto Formation, Fossati sub-basin), Patagonia Argentina: Palaeoenvironmental and climatic signficance: Sedimentary Geology, v. 296, p. 103-121.

Calvo, J.P., Alonso Zarza, A.M., and García del Cura, M.A., 1989, Models of Miocene marginal lacustrine sedimentation in response to varied depositional regimes and source areas in the Madrid Basin (central Spain): Palaeogeography, Palaeoclimatology, Palaeoecology, v. 70, p. 199-214.
Capezzuoli, E., Gandin, A., and Pedley, M., 2014, Decoding tufa and travertine (fresh water carbonates) in the sedimentary record: the state of the art: Sedimentology, v. $61, \mathrm{p}$. $1-21$

Casado, A.I., Alonso-Zarza, A.A., And La Iglesia, A., 2014, Morphology and origin of dolomite in paleosols and lacustrine sequences: examples from the Miocene of the Madrid Basin: Sedimentary Geology, v. 312, p. 50-62.

Chan, M., Netoff, D., Blakey, R., Kocurek, G., and Alvarez, W., 2007, Clastic-injection pipes and syndepositional deformation structures in Jurassic eolian deposits: examples from the Colorado Plateau, in Hurst, A., and Cartwright, J., eds., Sand Injectites: Implications for Hydrocarbon Exploration and Production: American Association of Petroleum Geologists, Memoir 87, p. 233-244.

Chan, M.A., Parrish, J.T., and Hasiotis, S.T., 2015, Dynamic soft-sediment deformation in the Jurassic Navajo Sandstone eolianite, Moab, Utah [Abstract]: Geological Society of America, Abstracts with Programs, Paper 256-3.

Chidsey, T.C., JR., Vanden Berg, M.D., and Eby, D.E., 2015, Petrography and characterization of microbial carbonates and associated facies from modern Great Salt Lake and Uinta Basins' Eocene Green River Formation in Utah, USA, in Bosence, D., Gibbons, K., Le Heron, D.P., Morgan, W.A., Pritchard, T., and Vining, B.A., eds., Microbial Carbonates in Space and Time: Implications for Global Exploration and Production: Geological Society of London, Special Publication 418, p. 261-286.

Choquette, P.W., and Pray, L.C., 1970, Geologic nomenclature and classification of porosity in sedimentary carbonates: American Association of Petroleum Geologists, Bulletin, v. 54, p. 205-250

Condon, S.M., 1992, Geologic framework of pre-Cretaceous rocks in the southern Ute Indian Reservation and adjacent areas, southwestern Colorado and northwestern New Mexico, in Geology and Mineral Resources of the Southern Ute Indian Reservation: U.S Geological Survey, Professional Paper 1505-A, 56 p.

Crossey, L.J., Karlstrom, K.E., Newell, D., Kooser, A., and Tafoya, A., 2011, The La Madera travertines, Rio Ojo Caliente, northern New Mexico: investigating the linked system of $\mathrm{CO}_{2}$-rich springs and travertines as neotectonic and paleoclimate indicators: Geology of the Tusas Mountains-Ojo Caliente, New Mexico Geological Society Guidebook, 62nd Field Conference, p. 301-316

DABKowski, J., Brou, L., AND Naton, H.-G., 2015a, New stratigraphic and geochemical data on the Holocene environment and climate from a tufa deposit at Direndall (Mamer Valley, Luxembourg): The Holocene, v. 25, p. 1153-1164.

Dabkowski, J., Royle, S.H., Antoine, P., Marca-Bell, A., And Andrews, J.E., 2015b, Highresolution $\delta^{18} \mathrm{O}$ seasonality record in a French Eemian tufa stromatolite (Caours, Somme Basin): Palaeogeography, Palaeoclimatology, Palaeoecology, v. 438, p. 277-284.

Della Porta, G., 2015, Carbonate build-ups in lacustrine, hydrothermal, and fluvial settings: comparing depositional geometry, fabric types and geochemical signature, in Bosence, D., Gibbons, K., Le Heron, D.P., Morgan, W.A., Pritchard, T., and Vining, B.A., eds., Microbial Carbonates in Space and Time: Implications for Global Exploration and Production: Geological Society of London, Special Publication 418, p. 17-68.

Demicco, R.V., Bridge, J.S., AND Cloyd, K.C., 1987, A unique freshwater carbonate from the Upper Devonian Catskill Magnafacies of New York State: Journal of Sedimentary Petrology, v. 57 , p. $327-334$.

DenNison, J.M., AND SHEA, J.H., 1966, Reliability of visual estimates of grain abundance: Journal of Sedimentary Petrology, v. 36, p. 81-89.

Dickson, J.A.D., 1965, A modified staining technique for carbonates in thin section: Nature, v. 205, p. 587

Dorney, L.J., AND Parrish, J.T., 2009, Carbonate mound structures in the Jurassic Navajo Formation of southeastern Utah [Abstract]: Geological Society of America, Programs with Abstracts, v. 41, p. 33.

Drake, N.A., EckardT, F.D., AND White, K.H., 2004, Sources of sulphur in gypsiferous sediments and crusts and pathways of gypsum redistribution in southern Tunisia: Earth Surface Processes and Landforms, v. 29, p. 1459-1471.

Driese, S.G., 1985, Interdune pond carbonates, Weber Sandstone (PennsylvanianPermian), northern Utah and Colorado: Journal of Sedimentary Petrology, v. 55, p. $187-195$.

DunaGan, S.P., 1999, A North American freshwater sponge (Eospongilla morrisonensis new genus and species) from the Morrison Formation (Upper Jurassic), Colorado: Journal of Paleontology, v. 73, p. 389-393.

Eisenberg, L., 2003, Giant stromatolites and a supersurface in the Navajo Sandstone, Capitol Reef National Park, Utah: Geology, v. 31, p. 111-114.

Ekdale, A.A., Bromley, R.G., And Loope, D.B., 2007, Ichnofacies of an ancient erg: a climatically influenced trace fossil association in the Jurassic Navajo Sandstone, southern Utah, USA, in Miller, W., III, ed., Trace Fossils: Concepts, Problems, Prospects: Amsterdam, Elsevier, p. 562-574

Eppley, R.W., And Peterson, B.J., 1979, Particulate organic matter flux and planktonic new production in the deep ocean: Nature, v. 282, p. 677-680.

Fensham, R.J., and Fairfax, R.J., 2003, Spring wetlands of the Great Artesian Basin, Queensland, Australia: Wetlands Ecology and Management, v. 11, p. 343-362.

FlÜGEL, E., 2004, Microfacies of Carbonate Rocks: New York, Springer-Verlag, 920 p

Ford, T.D., AND Pedley, H.M., 1996, A review of tufa and travertine deposits of the world: Earth-Science Reviews, v. 41, p. 117-175

FREDERICKSON, J.A., AND DAVIS, B.M., 2017, First reported actinopterygian from the Navajo Sandstone (Lower Jurassic, Glen Canyon Group) of southern Utah, USA: Journal of Paleontology, v. 91, p. 548-553. 
Freytet, P., And Verrecchia, E.P., 2002, Lacustrine and palustrine carbonate petrography: an overview: Journal of Paleolimnology, v. 27, p. 221-237.

García Del Cura, M.A., SAnz-Montero, M.E., De Los Ríos, M., and Ascaso, C., 2014, Microbial dolomite in fresh water carbonate deposits: Sedimentology, v. 61, p. 41-55. Gierlowski-Kordesch, E.H., 2010, Lacustrine carbonates, in Alonso-Zarza, A.A., and Tanner, L.H., eds., Carbonates in Continental Settings: Facies, Environments and Processes: Amsterdam, Elsevier, Developments in Sedimentology 61, p. 1-101.

Gilland, J.K., 1979, Paleoenvironment of carbonate lens in the lower Navajo Sandstone near Moab, Utah: Utah Geology, v. 6, p. 29-38.

Graf, J.W., Carroll, A.R., AND Smith, M.E., 2015, Lacustrine sedimentology, stratigraphy and stable isotope geochemistry of the Tipton Member of the Green River Formation, in Smith, M.E., and Carroll, A.R., eds., Stratigraphy and Paleolimnology of the Green River Formation, Western USA: Dordrecht, Springer, Syntheses in Limnogeology 1, p $31-60$.

Gregory, H.E., And Moore, R.C., 1931, The Kaiparowits region, a geographic and geologic reconnaissance of parts of Utah and Arizona: U.S. Geological Survey, Professional Paper 164, $161 \mathrm{p}$.

Guo, X., And Chafetz, H.S., 2012, Large tufa mounds, Searles Lake, California: Sedimentology, v. 59 , p. $1509-1535$.

Guo, X., and Chafetz, H.S., 2014, Trends in $\delta^{18} \mathrm{O}$ and $\delta^{13} \mathrm{C}$ values in lacustrine tufa mounds: palaeohydrology of Searles Lake, California: Sedimentology, v. 61, p. 221-237.

Hanley, J.H., and Steidtmann, J.R., 1973, Petrology of limestone lenses in the Casper Formation, southernmost Laramie Basin, Wyoming and Colorado: Journal of Sedimentary Petrology, v. 43, p. 428-434.

Harshbarger, J.W., RePenning, C.A., AND IRwin, J.H., 1957, Stratigraphy of the uppermost Triassic and the Jurassic rocks of the Navajo country: U.S. Geological Survey, Professional Paper 291, 74 p.

Hasiotis, S.T., Parrish, J.T., AND Chan, M.A., 2015, Hidden diversity of a wet desert ecosystem: preliminary report on the ichnology of the Navajo Sandstone, southeastern Utah [Abstract]: Geological Society of America, Abstracts with Programs, Paper 175-5

Hasiotis, S.T., Parrish, J.T., and Chan, M.A., 2016, Ichnofossils of a wet desert depositional system, Lower Jurassic Navajo Sandstone, southeastern Utah: American Association of Petroleum Geologists, Annual Convention and Exhibition, Calgary, Alberta, Canada, June 19-22, Search and Discovery Article \#90259.

Herries, R.D., 1993, Contrasting styles of fluvial-aeolian interaction at a downwind erg margin: Jurassic Kayenta-Navajo transition, northeastern Arizona, USA, in North, C.P., and Prosser, D.J., eds., Characterization of Fluvial and Aeolian Reservoirs: Geological Society of London, Special Publication 73, p. 199-218.

Hutchison, C.S., 1974, Laboratory Handbook of Petrographic Techniques: New York, John Wiley \& Sons, $527 \mathrm{p}$

Ibarra, Y., Corsetti, F.A., Cheetham, M.I., and Feakins, S.J., 2014, Were fossil springassociated carbonates hear Zaca Lake, Santa Barbara, California, deposited under and ambient or thermal regime?: Sedimentary Geology, v. 301, p. 15-25.

Johnson, C.R., Ashley, G.M., De Wet, C.B., Dvoretsky, R., Park, L., Hover, V.C., Owen, R.B., AND McBrearty, S., 2009, Tufa as a record of perennial fresh water in a semi-arid rift basin, Kapthurin Formation, Kenya: Sedimentology, v. 56, p. 1115-1137.

Jones, B., And Renaut, R.W., 2010, Calcareous spring deposits in continental settings, in Alonso-Zarza, A.A., and Tanner, L.H., eds., Carbonates in Continental Settings: Facies, Environments and Processes: Amsterdam, Elsevier, Developments in Sedimentology 61, p. $177-224$

KenNard, J.M., AND JamES, N.P., 1986, Thrombolites and stromatolites: two distinct types of microbial structures: Palaios, v. 1, p. 492-503.

Keppel, M.N., Clarke, J.D.A., Halihan, T., Love, A.J., and Werner, A.D., 2011, Mound springs in the arid Lake Eyre South region of South Australia: a new depositional tufa model and its controls: Sedimentary Geology, v. 240, p. 55-70.

KOCUREK, G., 1988, First-order and super bounding surfaces in eolian sequences: bounding surfaces revisited: Sedimentary Geology, v. 56, p. 193-206.

KocureK, G., 2003, Limits on extreme eolian systems; Sahara of Mauritania and Jurassic Navajo Sandstone examples, in Chan, M.A., and Archer, A.W., eds., Extreme Depositional Environments: Mega End Members in Geologic Time: Geological Society of America, Special Paper 370, p. 43-52.

Lancaster, N., and Teller, J.T., 1988, Interdune deposits of the Namib Sand Sea: Sedimentary Geology, v. 55, p. 91-107.

LeGgitT, V.L., AND Cushman, R.A., JR., 2001, Complex caddisfly-dominated bioherms from the Eocene Green River Formation: Sedimentary Geology, v. 145, p. 377-396.

LegGitT, V.L., BiAgGi, R.E., AND BuchHeIM, H.P., 2007, Palaeoenvironments associated with caddisfly-dominated microbial-carbonate mounds from the Tipton Shale Member of the Green River Formation: Eocene Lake Gosiute: Sedimentology, v. 54, p. 661-699.

Lewis, G.E., Irwin, J.H., AND Wilson, R.F., 1961, Age of the Glen Canyon Group (Triassic and Jurassic) on the Colorado Plateau: Geological Society of America, Bulletin, v. 72, p $1437-1440$.

Loope, D.B., AND Rowe, C.M., 2003, Long-lived pluvial episodes during deposition of the Navajo Sandstone: Journal of Geology, v. 111, p. 223-232.

Loope, D.B., Rowe, C.M., AND JoECKEL, R.M., 2001, Annual monsoon rains recorded by Jurassic dunes: Nature, v. 412, p. 64-66.

Marzolf, J.E., 1983, Changing wind and hydrologic regimes during deposition of the Navajo and Aztec Sandstones, Jurassic (?), southwestern United States, in Brookfield M.E., and Ahlbrandt, T.S., eds., Eolian Sediments and Processes: Amsterdam, Elsevier, Developments in Sedimentology 38, p. 635-660.
McKeE, E.D., 1979, Introduction to a study of global sand seas, in McKee, E.D., ed., A Study of Global Sand Seas: U.S. Geological Survey, Professional Paper 1052, p. 1-19.

Mudd, G.M., 2000, Mound springs of the Gerat Artesian Basin in South Australia: a case study from Olympic Dam: Environmental Geology, v. 39, p. 463-476.

NETOFF, D., 2002, Seismogenically induced fluidization of Jurassic erg sands, south-central Utah: Sedimentology, v. 49, p. 65-80.

Nicoll, K., AND SAllam, E.S., 2016, Paleospring tufa deposition in the Kurkur Oasis region and implications for tributary integration with the River Nile in southern Egypt: Journal of African Earth Sciences, 13 p., doi: https://doi.org/10.1016/j.jafrearsci.2016.10.014

PARCELL, W.C., 2002, Sequence stratigraphic controls on the development of microbial fabrics and growth forms: implications for reservoir quality distribution in the Upper Jurassic (Oxfordian) Smackover Formation, eastern Gulf Coast, USA: Carbonates and Evaporites, v. 17, p. 166-181.

PARrish, J.T., 1993, Mesozoic climates of the Colorado Plateau: Museum of Northern Arizona, Bulletin 59, p. 1-11.

Parrish, J.T., And Dorney, L.J., 2009, Carbonate spring mounds and interdune lakes in the Navajo Sandstone (Jurassic, Western US): results of stable isotope analyses [Abstract]: Geological Society of America, Programs with Abstracts, Abstract 166362.

Parrish, J.T., and Falcon-Lang, H.J., 2007, Coniferous trees associated with interdune deposits in the Jurassic Navajo Sandstone Formation, Utah, USA: Palaeontology, v. 50, p. 829-843.

Parrish, J.T., Hasiotis, S.T., and Chan, M.A., 2016, Carbonates in the Jurassic Navajo Sandstone, Moab area, Utah: Geological Society of America, Rocky Mountain Section, Paper 13-3

Parrish, J.T., Hasiotis, S.T., and Chan, M.A., 2017, Carbonate deposits in the Lower Jurassic Navajo Sandstone, southern Utah and northern Arizona: Journal of Sedimentary Research, v. 87, p. 740-762.

Pearson, E.F., And Hanley, J.H., 1974, Significance of thin carbonates in interpreting the depositional environments of thick clastic sequences: University of Wyoming, Contributions to Geology, v. 13, p. 63-66.

Pedley, H.M., 1990, Classification and environmental models of cool freshwater tufas: Sedimentary Geology, v. 68, p. 143-154.

Pedley, M., 2009, Tufas and travertines of the Mediterranean region: a testing ground for freshwater carbonate concepts and developments: Sedimentology, v. 56, p. 221-246.

Pedone, V.A., And Dickson, J.A.D., 2000, Replacement of aragonite by quasirhombohedral dolomite in a late Pleistocene tufa mound, Great Salt Lake, Utah, U.S.A.: Journal of Sedimentary Research, v. 70, p. 1152-1159.

Pentecost, A., 1996, The Quaternary travertine deposits of Europe and Asia Minor: Quaternary Science Reviews, v. 14, p. 1005-1028.

Pentecost, A., 2005, Travertine: Berlin, Springer-Verlag, 445 p.

Pentecost, A., And Viles, H., 1994, A review and reassessment of travertine classification: Géographie Physique et Quaternaire, v. 48, p. 305-314.

Peterson, F., And PipiRIngos, G.N., 1979, Stratigraphic relations of the Navajo Sandstone to Middle Jurassic Formation, southern Utah and northern Arizona: U.S. Geological Survey, Professional Paper 1035-B, 43 p.

Peterson, F., and Turner-Peterson, C., 1989, Geology of the Colorado Plateau: Washington, D.C., American Geophysical Union, 65 p.

PhoEnix, D.A., 1963, Geology of the Lees Ferry area, Coconino County, Arizona: U.S. Geological Survey, Bulletin 1137, $86 \mathrm{p}$.

Pope, M.C., AND Grotzinger, J.P., 2000, Controls on fabric development and morphology of tufas and stromatolites, uppermost Pethei Group $(1.8 \mathrm{Ga})$, Great Slave Lake, Northwest Canada, in Grotzinger, J.P., and James, N.P., eds., Carbonate Sedimentation and Diagenesis in the Evolving Precambrian World: SEPM, Special Publication 67, p. 103-121.

PRATt, B.R., AND JAmes, N.P., 1982, Cryptalgal-metazoan bioherms of early Ordovician age in the St George Group, western Newfoundland: Sedimentology, v. 29, p. 543-569.

Priewisch, A., Crossey, L.J., Karlstrom, K.E., Polyak, V.J., Asmerom, Y., Nereson, A., AND RicketTS, J.W., 2014, U-series geochronology of large-volume Quaternary travertine deposits of the southeastern Colorado Plateau: evaluating episodicity and tectonic and paleohydrologic controls: Geosphere, v. 10, p. 401-423.

Raviolo, M.M., Bordonaro, O.L., and Pratt, B.R., 2010, Trombolitos (arrecifes microbiales) del morofgénero Favosamaceria en el Cámbrico Superior de la Precordillera Oriental, San Juan, Argentina: Ameghiniana, v. 47, p. 331-341.

Rhodes, M.K., and CARroll, A.R., 2015, Lake type transition from balanced-fill to overfilled: Laney Member, Green River Formation, Washakie Basin, Wyoming, in Smith, M.E., and Carroll, A.R., eds., Stratigraphy and Paleolimnology of the Green River Formation, Western USA: Dordrecht, Springer, Syntheses in Limnogeology 1, p. $103-125$.

Riding, R., 1999, The term stromatolite: towards an essential definition: Lethaia, v. 32, p. 321-330.

Riding, R., 2000, Microbial carbonates: the geological record of calcified bacterial-algal mats and biofilms: Sedimentology, v. 47, p. 179-214.

RIDING, R., 2011, The nature of stromatolites: 3,500 million years of history and a century of research, in Reitner, J., Quéric, N.-V., and Arp, G., eds., Advances in Stromatolite Geobiology: Heidelberg, Springer, Lecture Notes in Earth Sciences 131, p. 29-74.

RigGs, N.R., AND Blakey, R.C., 1993, Early and middle Jurassic paleogeography and volcanology of Arizona and adjacent areas, in Dunne, G., and McDougall, K., eds., Mesozoic Paleogeography of the Western United States, II: SEPM, Pacific Section, Book 71, p. 347-375. 
Roberts, C.R., And Mitchell, C.W., 1987, Spring mounds in southern Tunisia, in Frostick, L.E., and Reid, I., eds., Desert Sediments: Ancient and Modern: Geological Society of London, Special Publication 35, p. 321-334.

Rogerson, M., Pedley, H.M., Wadhawan, J.D., and Middleton, R., 2008, New insights into biological influence on the geochemistry of freshwater carbonate deposits: Geochimica et Cosmochimica Acta, v. 72, p. 4976-4987.

Rosen, M.R., Arehart, G.B., And Lico, M.S., 2004, Exceptionally fast growth rate of < 100-yr-old tufa, Big Soda Lake, Nevada: implications for using tufa as a paleoclimate proxy: Geology, v. 32, p. 409-412.

Rosenberg, T.M., Preusser, F., Risberg, J., Plikk, A., Kadi, K.A., Matter, A., And Fleitmann, D., 2013, Middle and Late Pleistocene humid periods recorded in palaeolake deposits of the Nafud desert, Saudi Arabia: Quaternary Science Reviews, v. 70, p. 109123.

Sarg, J.F., Suriamin, N., Tänavsuu-Milkeviciene, K., and Humphrey, J.D., 2013 Lithofacies, stable isotopic composition, and stratigraphic evolution of microbial and associated carbonates, Green River Formation (Eocene), Piceance Basin, Colorado: American Association of Petroleum Geologists, Bulletin, v. 97, p. 1937-1966.

Schmid, D.U., 1996, Marine Microbolithe und Microinkrustierer aus dem Oberjura: Profil, v. 9 , p. $101-251$

Scholl, D.W., 1960, Pleistocene algal pinnacles at Searles Lake, California: Journal of Sedimentary Petrology, v. 30, p. 414-431.

Scholle, P.A., And Ulmer-Scholle, D.S., 2003, A Color Guide to the Petrography of Carbonate Rocks: Grains, Textures, Porosity, Diagenesis: American Association of Petroleum Geologists, Memoir 77, 474 p.

Seard, C., Camoin, G., Rouchy, J.-M., and Virgone, A., 2013, Composition, structure an evolution of a lacustrine carbonate margin dominated by microbialites: case study from the Green River Formation (Eocene; Wyoming, USA): Palaeogeography, Palaeoclimatology, Palaeoecology, v. 381-382, p. 128-144.

ShaPIRO, R.S., 2000, A comment on the systematic confusion of thrombolites: Palaios, v. 15 , p. $166-169$.

Shiraishi, F., Reimer, A., Bissett, A., De Beer, D., and Arp, G., 2008, Microbial effects on biofilm calcification, ambient water chemistry and stable isotope records in a highly supersaturated setting (Westerhöfer Bach, Germany): Palaeogeography, Palaeoclimatology, Palaeoecology, v. 262, p. 91-106.

SigLeO, A.C., 1979, Geochemistry of silicified wood and associated sediments, Petrified Forest National Park, Arizona: Chemical Geology, v. 26, p. 151-163.

Stokes, W.L., 1991, Petrified mini-forests of the Navajo Sandstone, east-central Utah: Utah Geological Survey, Bulletin, v. 25, p. 14-19.

Swanson, S.K., Muldoon, M.A., Polyak, V., And Asmerom, Y., 2014, Evaluating shallow flow-system response to climate change through analysis of spring deposits in southwestern Wisconsin, USA: Hydrogeology Journal, v. 22, p. 851-863.

Teller, J.T., Rutter, N., and Lancaster, N., 1990, Sedimentology and paleohydrology of Late Quaternary lake deposits in the northern Namib sand sea, Namibia: Quaternary Science Reviews, v. 9, p. 343-364

Valero Garcés, B.L., Moreno, A., Navas, A., Mata, P., Machin, J., Delgado Huertas, A., González Sampériz, P., Schwalb, A., Morellón, M., Cheng, H., and Edwards, R.L., 2008, The Taravilla lake and tufa deposits (Central Iberian Range, Spain) as palaeohydrological and palaeoclimatic indicators: Palaeogeography, Palaeoclimatology, Palaeoecology, v. 259, p. 136-156.

Viles, H.A., AND Goudie, A.S., 1990, Tufas, travertines and allied carbonate deposits Progress in Physical Geography, v. 14, p. 19-41.

Wendorf, F., AND Schild, R., 1980, Prehistory of the Eastern Sahara: New York, Academic Press, $414 \mathrm{p}$.

Wendorf, F., Schild, R., Said, R., Haynes, C.V., Gautier, A., and Kobusiewicz, M., 1976, The prehistory of the Egyptian Sahara: Science, v. 193, p. 103-114.

WiLKENS, N.D., 2008, Paleoecology of Early Jurassic Navajo Sandstone Interdune Deposits [PhD thesis]: Arizona State University, $417 \mathrm{p}$.

Wilkens, N.D., And Farmer, J., 2005, Paleoecology of the Navajo Sandstone interdune deposits: Canyon Legacy, v. 54, p. 39-42.

Wilkens, N.D., Farmer, J., And PigG, K., 2005, Exceptional paleobotanical remains preserved in Navajo Sandstone interdune deposits near Moab, Utah [Abstract] Geological Society of America, Abstracts with Programs, v. 37, p. 527

Received 9 January 2016; accepted 30 July 2017. 